

\title{
The Apparent Polar Wander Path of the Tarim block (NW China) since the Neoproterozoic and its implications for a long-term Tarim-Australia connection
}

Pan Zhao, Yan Chen, Sheng Zhan, Bei Xu, Michel Faure

\section{- To cite this version:}

Pan Zhao, Yan Chen, Sheng Zhan, Bei Xu, Michel Faure. The Apparent Polar Wander Path of the Tarim block (NW China) since the Neoproterozoic and its implications for a long-term TarimAustralia connection. Precambrian Research, 2014, 242, pp.39-57. 10.1016/j.precamres.2013.12.009 . insu-00931952

\section{HAL Id: insu-00931952 \\ https://hal-insu.archives-ouvertes.fr/insu-00931952}

Submitted on 7 Feb 2014

HAL is a multi-disciplinary open access archive for the deposit and dissemination of scientific research documents, whether they are published or not. The documents may come from teaching and research institutions in France or abroad, or from public or private research centers.
L'archive ouverte pluridisciplinaire HAL, est destinée au dépôt et à la diffusion de documents scientifiques de niveau recherche, publiés ou non, émanant des établissements d'enseignement et de recherche français ou étrangers, des laboratoires publics ou privés. 
The Apparent Polar Wander Path of the Tarim block (NW China) since the Neoproterozoic and its implications for a long-term Tarim-Australia connection



${ }^{1 .}$ Key Laboratory of Orogenic Belts and Crustal Evolution, Ministry of Education, Peking University, Beijing, 100871, China

2. Institut des Sciences de la Terre d'Orléans, UMR 7327-Université d'Orléans-INSU/CNRS-BRGM, 1A rue de la Férollerie, 45071 Orléans, Cedex 2, France

${ }^{3 .}$ Blackstone Mining Associates Limited, 100 Queens Road, Central, Hong Kong, China

*Corresponding author E-mail address: bxu@pku.edu.cn 
Abstract

In order to better understand the kinematic history of the Tarim block after the breakup of the Rodinia supercontinent, paleomagnetic studies have been carried out on Neoproterozoic strata from the Quruqtagh and Yecheng areas in the northeastern and southwestern Tarim block (NW China), respectively. Totally, 547 sedimentary and volcanic samples were collected from 64 sites. Magnetic mineralogical studies show that titanium-poor magnetite and hematite are the principal magnetic remanent carriers. For the Quruqtagh area, the directional analyses reveal that the stable and primary magnetic remanences have been isolated from the ca. 635Ma Tereeken Formation cap carbonate and the 615Ma Zhamoketi basaltic andesite, providing two Neoproterozoic paleomagnetic poles at: $\lambda=27.6^{\circ} \mathrm{N}, \varphi=140.4^{\circ} \mathrm{E}, \mathrm{dp}=8.8^{\circ}, \mathrm{dm}=11.1^{\circ}$ for the Tereeken formation and $\lambda=-4.9^{\circ} \mathrm{N}, \varphi=146.7^{\circ} \mathrm{E}, \mathrm{dp}=3.0^{\circ}, \mathrm{dm}=5.2^{\circ}$ for the Zhamoketi formation. Nevertheless, all other Neoproterozoic formations from this area show magnetic directions close to either the Present Earth Field (PEF) or the Late Carboniferous-Early Permian ones. Samples from the Yecheng area yield high anisotropy degree values and near vertical magnetic fabrics indicating the absence of reliable Neoproterozoic magnetic remanence. Combined these two newly obtained paleomagnetic poles with the previously published ones, an Apparent Polar Wander Path (APWP) from the Neoproterozoic to the Present has been built for the Tarim block. The comparison between the APWPs of Tarim and Australia implies a long-term Australia-Tarim connection and/or same kinematic evolution from at least the Neoproterozoic until the Middle Silurian. The Tarim block probably began to 
break away from northwestern Australia since the Late Ordovician and the final separation occurred at the Late Silurian-Early Devonian.

Key words: Neoproterozoic; Paleomagnetism; Tarim block; Australia; APWP

\section{Introduction}

The western part of the Rodinia supercontinent, composed of Australia, East Antarctica, India, South China and Tarim (Li et al., 1996; Li and Powell, 2001; Powell and Pisarevsky, 2002), was considered to break up from the Rodinia supercontinent during 800-700 Ma rifting events (Meert and Torsvik, 2003; Li et al., 2008). After the breakup, each block displayed a different kinematic history. For East Antarctica, it situated against the southern margin of Australia and evolved together with Australia (Li et al., 2008). Concerning the India block, it separated from the western part of Australia and drifted northwestwards at the beginning of the Rodinia breakup event (Torsvik et al., 2001; Li et al., 2008; Gregory et al., 2009). While for the drift history of the Tarim block after the Rodinia breakup, different ideas have been proposed. Chen et al. (2004) and Zhan et al. (2007) suggested that the Tarim block was situated against northwestern Australia at $\sim 800 \mathrm{Ma}$ and $\sim 600 \mathrm{Ma}$. In a recent reconstruction model ( $\mathrm{Li}$ et al., 2008), the Tarim block was placed at northwestern Australia and moved together with Australia during the entire Late Neoproterozoic. However, Huang et al. (2005) proposed that the Tarim block was situated against Southwest Australia at ca. $740 \mathrm{Ma}$ after a southward drift and a counterclockwise rotation. It is obvious that further paleomagnetic studies from geochronologically well constrained 
strata can provide critical answers for these controversies and the kinematic history of the Tarim block. For this reason, in this paper, we present new Late Neoproterozoic paleomagnetic data from the Quruqtagh and Yecheng areas in the northeastern and southwestern parts of the Tarim block, respectively. With these new results and the previous paleomagnetic data, we try to build up the Apparent Polar Wander Path (APWP) of the Tarim block and discuss its kinematic history after the breakup of the Rodinia supercontinent.

2. Geological setting and paleomagnetic sampling

\subsection{Geological setting}

The Tarim block, situated in northwestern China (Fig. 1a), is bounded by the Tianshan Mountain to the north, the Western Kunlun Mountain to the southwest, and the Altyn Tagh Fault to the southeast (Fig. 1b). Archean gneisses and Paleo- to Mesoproterozoic metasedimentary and metavolcanic rocks constitute the basement of the Tarim block (Lu et al., 2008). The cratonization of the Tarim block occurred between $1.05 \mathrm{Ga}$ to $0.9 \mathrm{Ga}$ by the Tarimian Orogeny with the Aksu blueschist dated at 962 $\pm 12 \mathrm{Ma}$ and 944 $\pm 12 \mathrm{Ma}$ (Gao et al., 1993; Lu et al., 2008). The basement was intruded by middle Neoproterozoic mafic dykes and granitoid plutons with a peak age at $800 \mathrm{Ma}$, which attributed to the breakup of the Rodinia supercontinent ( $\mathrm{Lu}$ et al., 2008; Zhang et al., 2007, 2009; Shu et al., 2011). The middle Neoproterozoic to Phanerozoic sedimentary rocks unconformably covered the metamorphic basement and intrusions (Gao et al., 1993; Lu et al., 2008). Late Neoproterozoic diamictite 
bearing deposits have been identified from three areas in the Tarim block, namely Quruqtagh on the northeastern margin, Aksu on the northwestern margin and Yecheng on the southwestern margin (Fig. 1b; Lu et al., 2008). Three glaciations have been described from the Quruqtagh area (Xu et al., 2009), while two glaciations have been identified from the Aksu and Yecheng areas (Zhu and Wang, 2012; Tong et al., in press). As paleomagnetic studies have been already performed on the Neoproterozoic dykes and strata in the Aksu area (Li et al., 1991; Chen et al., 2004; Zhan et al., 2007; Wen et al., 2013), this study focuses on the Quruqtagh and Yecheng areas.

\subsubsection{Quruqtagh area}

The Quruqtagh area is located on the northeastern margin of the Tarim block, NW China (Fig. 1). The oldest Archean Tuoge Complex is composed of granitic gneisses with minor amphibolites (Lu et al., 2008; Long et al., 2010; Zhang et al., 2012a). The Paleoproterozoic gneisses and marbles underwent amphibolite- to granulite-facies metamorphism and are unconformably overlain by the Mesoproterozoic low-grade metamorphosed clastic and volcanic rocks (XJBGMR, 1993; Lu et al., 2008). The Neoproterozoic strata are characterized by several layers of diamictites and volcanic rocks, separated by shale, sandstone and limestone (Xiao et al., 2004; Xu et al., 2009). The Neoproterozoic Quruqtagh succession includes, stratigraphically from the bottom to the top, the Baiyisi, Zhaobishan, Altungol, Tereeken, Yukengol, Zhamoketi, Shuiquan and Hankalchough formations (Figs. 2a and 2b). Three glaciations, i.e. Baiyisi, Tereeken and Hancalchough, have been recognized from the Baiyisi, Altungol, Tereeken and Hankalchough formations (Wang 
et al., 1981; Gao and Qian, 1985; Brookfield, 1994; Knoll, 2000; Xiao et al., 2004; Xu et al., 2009). Volcanic rocks from the bottom and top of the Baiyisi formation yield zircon $\mathrm{U}-\mathrm{Pb}$ ages of $740 \pm 7 \mathrm{Ma}$ and $725 \pm 10 \mathrm{Ma}$, respectively. And volcanic rocks from the top of the Zhamoketi formation gives a zircon $\mathrm{U}-\mathrm{Pb}$ age of $615 \pm 6 \mathrm{Ma}$ (Xu et al., 2009). Meanwhile, Chemo-stratigraphic and sedimentary features of the Tereeken diamictite suggest a Marinoan age (ca. 635Ma) for the Tereeken glaciation (Xiao et al., 2004). Except for these four diamictite-bearing formations, interglacial deposits contain interbedded sandstone -shale of the Zhaobishan and Zhamoketi formations, carbonate of the Shuiquan formation and shale of the Yukengou formation (Fig. 1d). The lower Cambrian siliceous rocks unconformably overlie the Quruqtagh succession (Xu et al., 2005).

\subsubsection{Yecheng area}

The Yecheng area is located in the southwest of the Tarim block, which is separated from the Tibetan plateau to the south along the West Kunlun Mountain (Fig. 1b). The Proterozoic strata crop out at ca. $100 \mathrm{~km}$ south of Yecheng city. The strata include, in ascending order, the Silu Group of the Qingbaikou series, the Yalaguz formation and the Qakmaklik Group of the Nanhua (Cryogenian) series, the Kurcak and Kzisuhum formations of the Sinian (Ediacaran) series (Fig. 2c). These Neoproterozoic formations are unconformably overlain by the Devonian clastic-carbonate rocks. The Silu Group of the Qingbaikou series is mainly composed of weakly deformed sandstone and dolomite with abundant of stromatolite and algae fossils, e.g. Gymonsolen, Inzeria, Oscillatorites sp., Polyedryxium sp., which well 
constrain its age (Wang et al., 2004; Zhang et al., 2003, 2004). It unconformably overlies Paleo- and Mesoproterozoic gneisses (Ma et al., 1991; Zhang et al., 2003). Both the gneisses and the Silu Group were intruded by granites and mafic dykes dated at $815-800 \mathrm{Ma}$ (Zhang et al., 2003, 2004). In turn, the Silu Group and mafic dykes are unconformably overlain by the Yalaguz formation conglomerate (Fig. 2c; Zhang et al., 2004; Wang et al., 2004). The Yalaguz Formation mainly consists of versicolor conglomerate with interbedded siltstone (Zhang et al., 2003). The Qakmaklik Group is upwardly composed of the Polong, Kelixi and Yutang formations (Fig. 1c). The Polong formation consists of purple-green siltstone and mudstone at the lower part and thick dark purple tillite at the upper part, which is considered as marine glacier deposits (Zhang et al., 2003; Tong et al., in press). The Kelixi formation consists of red sandstone and conglomerate with large trough-planar cross beddings, considered as delta or peritidal deposits (Zhang et al., 2003; Tong et al., in press). The Yutang formation contains dark purple tillite at the lower part and red sandstone-siltstone on the upper part. No direct bio-stratigraphic age has been obtained from the Qakmaklik Group because of rare fossils therein. The Sinian strata, composed of the Kzisuhum and Kurcak formations, are mainly made up of dolomite, red-black sandstone and mudstone with characteristic gypsum layers (Tong et al., in press). The wealth of stromatolite and algae fossils, e.g. Trematosphaeridium sp., Polyedryxium sp., Pseudozonosphaera rugosa, well constrain their age and make this series comparable with the Hankalchough formation in the Quruktagh area (Gao et al., 1985).

2.2 Paleomagntic sampling 
In the field, 6 to 12 cores were drilled from each site using a portable gasoline drill. Cores were oriented by both magnetic and solar compasses, when it was possible. The average difference between these two azimuth measurements is about $2.2 \pm 1.6^{\circ}$ for the Quruqtagh area and $4.0^{\circ} \pm 1.8^{\circ}$ for the Yecheng area. This mean value is used for the orientation corrections for the samples measured only by magnetic compass as well as for the sedimentary bedding measurement.

In the Quruktagh area, paleomagnetic samples were collected from 6 out of 8 Late Neoproterozoic formations except the Baiyisi and Yukengou formations (Fig. 2c). Totally, 392 cores of 52 sites were paleomagnetically sampled (Fig. 2a; Table 1). Most samples were collected from the Heishan-Zhaobishan area in the central part of the Quruqtagh area (ca. 200km southeast of Korla, Fig. 2a), with 4 sites of the Zhaobishan formation collected from the same section in the Xishankou area where the paleomagnetic results of the Baiyisi volcanic rocks were published (Huang et al., 2005). A notable fact of the strata from the Xishankou area is that the green-colored volcanic rocks contain metamorphic chlorite. Detailed sampling information can be found in Table 1.

In the Yecheng area, paleomagnetic samples were collected from the red sandstone of the Kelixi formation between two tillite layers (Fig. 2d) at the West Kunlun Mountain front (Fig. 1b). The strata are intensively tilted with high angle bedding (Fig. 2d; Table 1). Several faults have been observed in the sampling zone (Fig. 2c). Two folds were identified within the Kelixi Formation (Fig. 1d), providing a good opportunity for future fold test. Totally, 155 samples of 12 sites were collected 
from both limbs of folds (Table 1).

\section{Laboratory methods}

In the laboratory, cores were prepared into standard specimens with $2.5 \mathrm{~cm}$ in diameter and $2.2 \mathrm{~cm}$ in length. Before the measurements of magnetic remanence of this paleomagnetic collection, several methods were performed to investigate the magnetic mineralogy: thermal magnetic experiment (Curie point) by KLY-3S kappabridge susceptibility-meter coupled with a CS3 furnace and acquisition of isothermal remanent magnetization (IRM) by IM30 pulse magnetizer and JR5A magnetometer in the Laboratoire de Magnétisme des Roches d'Orléans (LMRO), and magnetic hysteretic curves in the Laboratoire de Paleomagnétisme of Institut de Physique du Globe de Paris (IPGP) at Saint Maur.

In order to evaluate the deformation experienced by sampled rocks, measurements of the anisotropy of the magnetic susceptibility (AMS) were also systematically performed on specimens before their demagnetization by KLY3 kappabridge susceptibility-meter. The orientation of the principal magnetic fabric axes, namely $\mathrm{K}_{1}, \mathrm{~K}_{2}$ and $\mathrm{K}_{3}$, has been measured, and the anisotropy degree $\left(\mathrm{P}_{\mathrm{J}}\right)$ and shape parameter (T) have been calculated for each specimen following Jelínek (1978).

Usually, at least 6 cores were chosen from each site for demagnetization. Both thermal and alternative magnetic field (AF) techniques were applied to progressively remove the magnetic remanence by about 12-16 steps with temperature intervals from 20 to $50^{\circ} \mathrm{C}$ and alternative magnetic field intervals from 2 to $20 \mathrm{mT}$. The majority of 
the sandstone specimens were measured in LMRO with JR5-A spinner magnetometer; the remaining samples were measured in IPGP with a $2 \mathrm{G}$ cryogenic magnetometer for comparison reason. Almost all limestone specimens were measured in IPGP with a $2 \mathrm{G}$ cryogenic magnetometer because of their low magnetic remanent intensity. No significant difference was found between the results of these two laboratories.

Magnetic directions were isolated by the principal component analysis method (Zijderveld, 1967; Kirschvink, 1980) or estimated by great circle technique when end-points were not aligned (McFadden and McElhinny, 1988). The mean magnetic directions were computed by Fisher spherical analysis (Fisher, 1953) using paleomagnetic software packages offered by Cogné (2003) and R. Enkin (unpublished).

4. Measurement results

\subsection{Quruqtagh area}

\subsubsection{Zhamoketi Formation}

For the sandstone of the Zhaobishan formation, isothermal magnetization measurements show a rapid increase until to $30 \mathrm{mT}$, then a slow increase of IRM without a total magnetic saturation at about $1.5 \mathrm{~T}$ (Fig. 3a), indicating the existence of both low and high magnetic coercive minerals in the rock. Thermal magnetic experiments reveal a gradually decrease of magnetic susceptibility and an obvious drop from $580^{\circ} \mathrm{C}$ to $700^{\circ} \mathrm{C}$ (Fig. 3b), indicating the existence of magnetite and hematite. The paramagnetic feature of hysteresis loop (Fig. 3c) may be caused by the 
weak amount of ferromagnetic minerals. Four sites of sandstone collected from the Xishankou area present two magnetic components (Fig. 4a). The low temperature component (LTC) displays northeastward declinations and downward inclinations (Fig. 4a). The high temperature component (HTC) gives unified southwestward declinations and upward inclinations (Fig. 4a), and a site-mean direction has been calculated at: $\mathrm{D}_{\mathrm{g}}=222.7^{\circ}, \mathrm{I}_{\mathrm{g}}=-38.6^{\circ}, \mathrm{k}_{\mathrm{g}}=27.5, \alpha_{95 \mathrm{~g}}=24.0^{\circ} ; \mathrm{D}_{\mathrm{s}}=227.2^{\circ}, \mathrm{I}_{\mathrm{s}}=-6.9^{\circ}, \mathrm{k}_{\mathrm{s}}=10.6$, $\alpha_{95 \mathrm{~s}}=40.0^{\circ}$ with $\mathrm{n}=3$ (Table 1). Tilt-corrected directions are less clustered than the in-situ directions with a $\mathrm{k}_{\mathrm{S}} / \mathrm{k}_{\mathrm{g}}$ ratio of 0.39 . Meanwhile, the optimal concentration of direction correction (DC) of tilt test is achieved at $-30 \%$ unfolding, with DC slope at $-0.317 \pm 0.600$ (Enkin, 2003). Both of them indicate a negative fold test at the $95 \%$ confidence level (McElhinny, 1964; Enkin, 2003; Figs. 5a and 5b; Table 1). The 8 sites from Heishan-Zhaobishan area show northward declinations and downward inclinations (Fig. 4b) with a site-mean direction at: $\mathrm{D}_{\mathrm{g}}=0.6^{\circ}, \mathrm{I}_{\mathrm{g}}=56.5^{\circ}, \mathrm{k}_{\mathrm{g}}=210.5$, $\alpha_{95 \mathrm{~g}}=3.8^{\circ} ; \mathrm{D}_{\mathrm{s}}=99.3^{\circ}, \mathrm{I}_{\mathrm{s}}=34.4^{\circ}, \mathrm{k}_{\mathrm{s}}=25.6, \alpha_{95 \mathrm{~s}}=11.2^{\circ}$ with $\mathrm{n}=8$ (Figs. $5 \mathrm{c}$ and $5 \mathrm{~d}$; Table 1 ). The mean direction in in-situ coordinates is close to the Present Earth Field (PEF; Figs. 5c and 5d) and a negative fold test is concluded (McElhinny, 1964; Enkin, 2003).

\subsubsection{Altungol Formation}

Eight sites of trachybasalt from the Altungol Formation were sampled in a monoclinal section. The abrupt increase of IRM up to $90 \%$ saturation at about $200 \mathrm{mT}$, and the magnetic hysteresis measurements (Figs. 3d and 3f) suggest mainly low coercive magnetic minerals in the rocks. Thermal magnetic experiment shows an 
evident drop of magnetic susceptibility at $580-620^{\circ} \mathrm{C}$ during the heating process (Fig. 3e), implying titanium-poor magnetite as the main magnetic mineral, which is confirmed by hysteresis curve (Fig. 3f). Two out of eight sites display too weak NRM to give reliable direction (Table 1). Only one component was isolated with northward declinations and downward inclinations from other 6 sites (Fig. 4c; Table 1). A site-mean direction has been calculated for this formation: $\mathrm{D}_{\mathrm{g}}=4.4^{\circ}, \mathrm{I}_{\mathrm{g}}=58.6^{\circ}, \mathrm{k}_{\mathrm{g}}=74.3$, $\alpha_{95 \mathrm{~g}}=7.8^{\circ} ; \mathrm{D}_{\mathrm{s}}=108.1^{\circ}, \mathrm{I}_{\mathrm{s}}=51.2^{\circ}, \mathrm{k}_{\mathrm{s}}=74.6, \alpha_{95 \mathrm{~s}}=7.8^{\circ}$ with $\mathrm{n}=6$ (Table 1). The mean direction in in-situ coordinates shows a close to the PEF direction (Figs. 5e and 5f) and no fold test could be applied because of the monoclinal bedding.

\subsubsection{Tereeken Formation}

Seven sites of carbonate were collected from the cap carbonate above the Tereeken tillite (Fig. 2c). The abrupt increase of IRM up to $90 \%$ saturation at about 200mT and narrow wasp-waisted hysteresis loops (Figs. 3g and 3i) suggest the predominant low coercive magnetic minerals in the rock. Thermal magnetic experiment shows an obvious drop of magnetic susceptibility from $540^{\circ} \mathrm{C}$ to $700^{\circ} \mathrm{C}$ during the heating process (Fig. 3h), implying the occurrence of both magnetite and hematite. The hysteresis curve reveals both lower and higher coercive magnetic minerals in the rock (Fig. 3i), Two components were isolated from most of the demagnetized samples distinguished at about $350^{\circ} \mathrm{C}$ (Fig. 4d) except for Site 623, which displays scattered directions due to its weak NRM (Table 1). The magnetic directions of the LTC (up to about $350^{\circ} \mathrm{C}$ ) display a close to the PEF direction in in-situ coordinates, and become dispersed in tilt corrected ones (Figs. 5g and 5h). 
After removing the LTC, the HTC shows a stable direction and a site-mean direction has been calculated at: $\mathrm{D}_{\mathrm{g}}=98.8^{\circ}, \mathrm{I}_{\mathrm{g}}=52.7^{\circ}, \mathrm{k}_{\mathrm{g}}=39.4, \alpha_{95 \mathrm{~g}}=10.8^{\circ} ; \mathrm{D}_{\mathrm{s}}=90.8^{\circ}, \mathrm{I}_{\mathrm{s}}=63.7^{\circ}$, $\mathrm{k}_{\mathrm{s}}=91.4, \alpha_{95 \mathrm{~s}}=7.0^{\circ}$ with $\mathrm{n}=6$ (Table 1). Tilt corrected directions are much more clustered than in-situ directions (Figs. 5i and 5j). Both McElhinny's and Enkin's fold tests give a positive answer for this formation (McElhinny, 1964; Enkin, 2003).

\subsubsection{Zhamoketi Formation}

Thirteen sites of basaltic andesite were sampled from the top of the Zhamoketi formation (Fig. 2c). IRM measurement shows an abrupt increase with the total saturation at about 200mT (Fig. 3j), indicating predominant low coercive magnetic minerals in the rock. Thermal magnetic experiment shows an obvious drop of magnetic susceptibility from $580^{\circ} \mathrm{C}$ to $600^{\circ} \mathrm{C}$ with subordinate decrease to $700^{\circ} \mathrm{C}$ (Fig. 3k), implying the presence of titanium-poor magnetite and some hematite. Although the low coercive minerals have been observed by hysteresis curves, the weak induced magnetization indicates a lower concentration of ferromagnetic mineral in the rock (Fig. 31). Among 13 sites, 4 sites display a viscous component without stable HTC and 3 sites present dispersed directions (Table 1). For the remaining 6 sites, two components were isolated from most of the demagnetized samples (Fig. 4e). The LTC (up to $250-350^{\circ} \mathrm{C}$ ) shows a close to the PEF direction in in-situ coordinates (Fig. 5k and 51). After removing the LTC, six sites show a unified HTC direction, and a site-mean direction has been calculated at: $\mathrm{D}_{\mathrm{g}}=56.9^{\circ}, \mathrm{I}_{\mathrm{g}}=66.9^{\circ}, \mathrm{k}_{\mathrm{g}}=222.6, \alpha_{95 \mathrm{~g}}=4.5^{\circ}$; $D_{s}=115.4^{\circ}, I_{s}=35.0^{\circ}, k_{s}=223.9, \alpha_{95 s}=3.5^{\circ}$ with $n=6$ (Figs. $5 \mathrm{~m}$ and 5n; Table 1). No fold test could be applied as the bedding is monoclinal. 


\subsubsection{Shuiquan Formation}

Four sites of basalt were sampled from the top of the Shuiquan formation (Fig. 2c). Both the abrupt IRM increase with a $90 \%$ saturation at about $300 \mathrm{mT}$ (Fig. $3 \mathrm{~m}$ ) and the wide wasp-waisted hysteresis loops (Fig. 3o) suggest low coercive magnetic minerals as the principal remanent carrier. Thermal magnetic experiment shows a sharp drop of magnetic susceptibility at around $580^{\circ} \mathrm{C}$ with the obvious Hopkinson effect before $580^{\circ} \mathrm{C}$ (Fig. 3n; Radhakrishnamurty and Likhite, 1970), confirming the titanium-poor magnetite as the principal remanent carrier. Only one magnetic component was isolated from this formation. Three sites display northwestward declinations and shallow downward inclinations (Fig. 4f) with one site showing eastward declinations and downward inclinations in in-situ coordinates (Table 1). A site-mean direction has been calculated at: $\mathrm{D}_{\mathrm{g}}=352.0^{\circ}, \mathrm{I}_{\mathrm{g}}=22.8^{\circ}, \mathrm{k}_{\mathrm{g}}=55.4, \alpha_{95 \mathrm{~g}}=16.7^{\circ}$; $\mathrm{D}_{\mathrm{s}}=351.1^{\circ}, \mathrm{I}_{\mathrm{s}}=0.6^{\circ}, \mathrm{k}_{\mathrm{s}}=30.2, \alpha_{95 \mathrm{~s}}=22.8^{\circ}$ with $\mathrm{n}=3$ (Table 1). Tilt corrected directions are less clustered than in-situ directions (Figs. 5o and 5p), indicating a negative fold test.

\subsubsection{Hankalchough Formation}

Eight sites of carbonate rocks were collected from the top of the Hankalchough formation (Fig. 2c). IRM measurement shows an abrupt increase with the total saturation at about 200mT (Fig. 3p), indicating predominant low coercive magnetic minerals in the rock. Thermal magnetic experiment shows a sharp drop of magnetic susceptibility from $560^{\circ} \mathrm{C}$ to $600^{\circ} \mathrm{C}$ with the obvious Hopkinson effect at about $560^{\circ} \mathrm{C}$ and subordinate decrease to $700^{\circ} \mathrm{C}$ (Fig. 3q), implying the existence of predominant 
titanium-poor magnetite and some hematite. The narrow wasp-waisted hysteresis loops (Fig. 3r) also suggest low coercive magnetic minerals as the magnetic remanent carrier. Only one component was isolated after removing the viscous component (Fig. 4g). All samples show a close to the PEF direction in in-situ coordinates and a site-mean direction has been calculated at: $\mathrm{D}_{\mathrm{g}}=19.6^{\circ}, \mathrm{I}_{\mathrm{g}}=59.3^{\circ}, \mathrm{k}_{\mathrm{g}}=331.1, \alpha_{95 \mathrm{~g}}=3.0^{\circ}$; $\mathrm{D}_{\mathrm{s}}=64.2^{\circ}, \mathrm{I}_{\mathrm{s}}=51.8^{\circ}, \mathrm{k}_{\mathrm{s}}=6.6, \alpha_{95 \mathrm{~s}}=23.2^{\circ}$ with $\mathrm{n}=8$ (Table 1). Tilt corrected directions are much less clustered than in-situ directions with a ratio of 0.02 for $\mathrm{ks} / \mathrm{kg}$, indicating a negative fold test (Figs. 5q and 5r).

\subsection{Yecheng area}

For the red sandstone of the Kelixi formation, both low and high coercive magnetic minerals were identified on the basis of gradually increase of IRM without a total magnetic saturation at $1.5 \mathrm{~T}$ (Fig. 3s) and wasp-waisted hysteresis without saturation (Fig. 3u). Thermal magnetic experiment shows three drops of magnetic susceptibility at around $100^{\circ} \mathrm{C}, 560-580^{\circ} \mathrm{C}$ and $680^{\circ} \mathrm{C}$ (Fig. 3t), indicating the coexistence of goethite, magnetite and hematite. Single or dual components were isolated after removing the random LTC (Figs. 4h and 4i). The HTC shows both normal and reversal polarities with antipodal magnetic directions (Figs. $4 \mathrm{~h}$ and $4 \mathrm{i}$ ). A site-mean direction has been calculated at: $\mathrm{D}_{\mathrm{g}}=5.2^{\circ}, \mathrm{I}_{\mathrm{g}}=27.9^{\circ}, \mathrm{k}_{\mathrm{g}}=7.2, \alpha_{95 \mathrm{~g}}=22.2^{\circ}$; $\mathrm{D}_{\mathrm{s}}=8.4^{\circ}, \mathrm{I}_{\mathrm{s}}=-18.4^{\circ}, \mathrm{k}_{\mathrm{s}}=48.5, \alpha_{95 \mathrm{~s}}=8.0^{\circ}$ with $\mathrm{n}=8$ (Table 1). Tilt corrected directions are more clustered than in-situ directions (Figs. 5s and 5t). Both McElhinny's and Enkin's fold test give positive answers for this formation (McElhinny, 1964; Enkin, 2003) and it also passes the reversal test (McFadden and McElhinny, 1990) 


\section{Discussion}

As the Tarim block experienced several important tectonic events since the Paleozoic, for instance, the continental collision between the Tarim block and the Kunlun block in the Early Paleozoic (Matte et al., 1996), the continental collision / welding of the Tarim block with Yili and Junggar blocks (Wang et al., 2007) in the Late Paleozoic, and the strike-slip related deformation along the margins of the Tarim block due to the India-Asia collision (Chen et al., 1993, 2002), before putting these paleomagnetic data for further tectonic interpretations, their reliability and remanence ages should be discussed.

\subsection{Reliability of paleomagnetic data}

\subsubsection{Rock deformation}

Although no direct evidence of a penetrative deformation (except tilting and folding of the strata) has been observed in the field in both studied areas, these sampled rocks have experienced polyphased tectonics since the Neoproterozoic. As mentioned above, the AMS measurements have been therefore carried out in order to further assess the effect of deformation. For the samples from the Quruqtagh area, a weak anisotropy has been observed with the anisotropy degree $\mathrm{P}_{\mathrm{J}}<1.08$ (Fig. 6a), indicating that these rocks have probably not experienced pervasive deformation since their deposition. However, it is not the case for the samples from the Yecheng area. The anisotropy degree is much bigger with about $30 \%$ samples showing $\mathrm{P}_{\mathrm{J}}$ value 
higher than 1.15 (Fig. 6b), which suggests that these rocks have probably experienced a pervasive deformation since their diagenesis. For further evaluation, the statistical results of the three principal magnetic anisotropic axes have also been calculated for these formations. For the Tereeken and Zhamoketi formations in the Quruqtagh area, well-grouped vertical $\mathrm{K}_{3}$ (poles of magnetic foliation: $\mathrm{D}=348.9^{\circ}, \mathrm{I}=77.8^{\circ}$ with $\alpha_{95 \max / \min }=28.1^{\circ} / 14.9^{\circ}$ and $\mathrm{D}=283.1^{\circ}, \mathrm{I}=81.3^{\circ}$ with $\alpha_{95 \max / \min }=29.2^{\circ} / 16.2^{\circ}$, respectively) have been obtained (Figs. 6c and 6d), indicating that the magnetic fabrics were developed during their deposition and the original deposition surface was close to horizontal. While for the Kelixi formation in the Yecheng area, a nearly horizontal $\mathrm{K}_{3}\left(\mathrm{D}=290.8^{\circ}, \mathrm{I}=9.5^{\circ} \alpha_{95 \max / \min }=32.1^{\circ} / 21.1^{\circ}\right)$ has been calculated (Fig. 6e), suggesting that the magnetic fabrics should be developed after the sedimentation, and the rocks have been affected by later tectonics as shown by their high anisotropy degree values. Therefore, the paleomagnetic directions from this formation will be excluded from the following discussion.

\subsubsection{Origins of magnetic remanence}

Among remained 6 formations in the Quruqtagh area, the magnetic direction analysis shows that only one, the Tereeken formation, passes the fold test, indicating that the remanence was acquired before the folding. During the Ordovician to the Middle Silurian, Central Tianshan Ocean subducted beneath the northeastern margin of Tarim (Wang et al., 2008; Charvet et al., 2011), causing the transition from Cambrian-Ordovician intra-craton extensional basin to Silurian-Devonian 
compressive uplift (Tang, 1997; Cheng et al., 2006), which may therefore be responsible for the absent of Silurian-Devonian sediments in most parts (Fang et al., 2006) and the folding of pre-Silurian strata of the Quruqtagh area. Since magnetite and hematite are the stable magnetic remanence carriers, and the sedimentary magnetic fabric is weak in the analyzed samples, the magnetic direction measured from this formation is likely primary. Moreover, this mean direction is significantly distinct from all those measured for Phanerozoic rocks (Zhu et al., 1998; Fang et al., 2006; Gilder et al., 2008; Huang et al., 2008). The corresponding paleomagnetic pole was therefore calculated at $\lambda=27.6^{\circ} \mathrm{N}, \varphi=140.4^{\circ} \mathrm{E}, \mathrm{dp}=8.8^{\circ}, \mathrm{dm}=11.1^{\circ}$ with $\mathrm{N}=6$. No fold test can be applied to the paleomagnetic directions from the Zhamoketi formation because of its monoclinal bedding attitude. Nevertheless, the HTC magnetic directions in tilt corrected coordinates are close to those of the Tereeken formation and Sugetbrak formation in the Aksu area (Zhan et al., 2007), and different from those of all other younger periods (Table 2). These observations argue for a primary origin of the magnetic remanence. Meanwhile, the volcanic rocks at the top of Zhamoketi Formation consist of $80-330 \mathrm{~m}$ thick basaltic and andesitic lavas and pyroclastic rocks in numerous layers of decimeter to several decimeters in thickness (Xu et al., 2009). Volcanic rocks and pyroclastic rocks are interbedded. This interbedded relationship indicates that the eruption of these volcanic rocks might last a long period with even several long intervals of eruption, implying that the Geomagnetic Secular Variation (GSV) has been averaged out. Consequently, a paleomagnetic pole for the Zhamoketi Formation was also calculated at: $\lambda=-4.9^{\circ} \mathrm{N}, \varphi=146.7^{\circ} \mathrm{E}, \mathrm{dp}=3.0^{\circ}, \mathrm{dm}=5.2^{\circ}$ with $\mathrm{N}=6$. 
All other formations display negative fold tests, indicating that they are of secondary magnetic remanences. The Zhaobishan formation from the Xishankou area displays the same direction of a sole reversal polarity with that of the Late Carboniferous-Early Permian formations indicating a remagnetization corresponding to the Late Carboniferous-Early Permian magmatic event developed in the northern margin of the Tarim block and southern Tianshan (Gao et al., 2009; Chen et al., 2011). The basalt samples from the Shuiquan formation display a direction different from any of the younger periods (Table 2), which may be ascribed to local fault movements (see Fig. 2a). Another reason for this abnormal direction may the short cooling time of basalt so that the secular variation has not been averaged out from the magnetic remanence from these rocks. All other formations display the recent geomagnetic directions (Fig. $5)$.

5.2 The age of primary magnetic remanences

The age constraints of glacier deposits in the Tarim block are obtained from zircon U-Pb dating of interlayered volcanic rocks (Xu et al., 2005, 2009) and chemostratigraphic correlations (Xiao et al., 2004; He et al., 2007). In the Quruqtagh area, two zircon SHRIMP U-Pb ages of $740 \pm 7 \mathrm{Ma}$ and $725 \pm 10 \mathrm{Ma}$ have been obtained in volcanic beds from the bottom and top of the Baiyisi Formation (Xu et al., 2009; Fig. 7), which constrain the Sturtian age for the Baiyisi glaciation, although the glacial origin of diamictites in the Baiyisi formation is still ambiguous (Xiao et al., 2004). The zircon U-Pb dating obtained from the top of the Zhamoketi formation (the 
same layer where we collected the paleomagnetic samples) yields a post-Marinoan age at $615 \pm 6 \mathrm{Ma}$ (Xu et al., 2009; Fig. 7), which constrains the age of our paleomagnetic pole of the Zhamoketi formation. The chemostratigraphic investigation of the Tereeken cap dolostone shows the same $\delta^{13} \mathrm{C}$ pattern as that of Marinoan cap carbonates (Xiao et al., 2004). Meanwhile, the characteristic macropeloids of Tereeken cap dolostone are similar to those found in the Marinoan-age Raventhroat cap carbonate (Xiao et al., 2004). Both of these two similarities constrain the Marinoan age of the Tereeken glaciation. Based on the dating of the Marinoan glaciation in the South China block from the Doushantuo cap carbonate (Condon et al., $2005)$, the termination age of this glaciation should be at $635.2 \pm 0.6 \mathrm{Ma}$. Therefore the age of our paleomagnetic pole obtained from the Tereeken formation should be at ca. $635 \mathrm{Ma}$.

\subsection{Apparent Polar Wander Path (APWP) of the Tarim block}

The paleomagnetic studies of the Tarim block began in 1980's (e.g. Bai et al., 1987; Li et al., 1990) and several syntheses have been tentatively established for the Phanerozoic with small paleomagnetic dataset (Nie et al., 1991; Enkin et la., 1992; Fang et al., 1998; Zhu et al., 1998). Since this century, new paleomagnetic poles have been reported (Gilder et al., 2003, 2008; Chen et al., 2004; Huang et al., 2005; Charreau et al., 2006; Zhan et al., 2007; Wen et al., 2013), two APWPs of Tarim have been built up, however, both of them concentrate on the only Paleozoic period (Fang et al., 2006; and Huang et al., 2008). Newly obtained Neoproterozoic results provide a 
good opportunity to extend the APWP for the Tarim block from the Neoproterozoic to Present by integrating the paleomagnetic poles published after 2008 and to discuss its kinematic history, especially in connection with Australia since the break-up of the Rodinia supercontinent. Before using the available Neoproterozoic poles into the APWP establishment, some assessments should be made on the age and reliability of the published data.

In the Aksu area, four Neoproterozoic poles have been reported (Fig. 7): one from Aksu dykes (Chen et al., 2004), one from the Qiaoenbrak Formation (Wen et al., 2013) and other two from the Sugetbrak Formation (Li et al., 1991; Zhan et al., 2007). The first zircon SHRIMP U-Pb age of Aksu dykes has been obtained at $807 \pm 12 \mathrm{Ma}$ (Chen et al., 2004). By newly obtained geochronological dating, Zhan et al. (2007) reassessed this age and considered that the age of this pole from the Aksu dykes should be at ca. 785Ma. Zhang et al. (2009) gave a new zircon SHRIMP U-Pb age of 759 \pm 7 Ma for Aksu dykes. Consequently, the intrusion of the Aksu dykes might last for a long period from ca. $807 \mathrm{Ma}$ to ca. $760 \mathrm{Ma}$. Recently, new ${ }^{40} \mathrm{Ar} /{ }^{39} \mathrm{Ar}$ ages on phengite from the metapelites of the Aksu blueschist were obtained at $748-757 \mathrm{Ma}$ (Yong et al., 2012). As the Aksu dykes crosscut the blueschists, they should be younger than 748Ma. However, the reported mafic dykes, gneissic granite and granodiorite along the margin of the Tarim block are from $824 \mathrm{Ma}$ to $752 \mathrm{Ma}$ (Zhang et al., 2012b), and are unconformably overlain by ca. 740Ma Baiyisi Formation in the Quruqtagh area (Shu et al., 2011). Besides, the ${ }^{40} \mathrm{Ar}-{ }^{39} \mathrm{Ar}$ isotopic system is easily to be disturbed by later thermal event with the relatively low closure temperature at 
$\sim 350-400^{\circ} \mathrm{C}$ (Lee, 1991; Maluski et al., 1993). The ${ }^{40} \mathrm{Ar} /{ }^{39} \mathrm{Ar}$ ages of blueschists may be related to the later thermal input due to intrusions and slow cooling. So, the SHRIMP zircon U-Pb ages may be the most reliable ones. In the following, we use an average $\mathrm{U}-\mathrm{Pb}$ age of $785 \mathrm{Ma}$ for the pole of Aksu dykes. For the $\sim 730 \mathrm{Ma}$ pole from the Qiaoenbrak Formation (Wen et al., 2013), the AMS study of this collection displays uncommon sedimentary fabrics: nearly vertical fabrics for both lineation and foliation before bedding corrections, and nearly vertical magnetic foliations with relatively well grouped and $\sim 30^{\circ}$ southwestward inclined magnetic lineation after bedding corrections. Meanwhile, the directions of magnetic lineation is highly consistent with the magnetic remanent directions, suggesting that the magnetic remanent orientation may be principally controlled by the tectonic deformation process or/and glacier deposition one, as the authors proposed, instead of the geomagnetic field. Accordingly, we deduce that this pole cannot be used to present the true paleomagnetic field for the period of $\sim 730 \mathrm{Ma}$ and is excluded from our APWP establishment. Two remained paleomagnetic poles obtained from the same stratigraphic part of the Sugetbrak Formation are significantly different (Li et al., 1991; Zhan et al., 2007; Table 2). In fact, the one from Li et al. (1990) is statistically indistinguishable from the Cretaceous poles of Tarim and could represent a Cretaceous overprint. Therefore, we use the pole from Zhan et al. (2007) for this formation. A new zircon $\mathrm{U}-\mathrm{Pb}$ age at $615 \pm 6 \mathrm{Ma}(\mathrm{Xu}$ et al., in review) has been recently obtained from the basaltic flow interlayered in the upper Sugetbrak formation, which may constrain the age estimation for this pole. Another approach to estimate 
this age concerns the correlation of the $\delta^{13} \mathrm{C}$ chemostratigtaphic variation between the Sugetbrak formation and the Doushantuo formation in the South China block. These two formations show a similar variation pattern (He et al., 2007; Zhan et al., 2007). The Doushantuo cap carbonate has been dated by numerous studies and gives a zircon U-Pb age of 635.2 $\pm 0.6 \mathrm{Ma}$ (e.g. Condon et al., 2005). This age constrains the lower limit of the Sugetbrak formation. Therefore, the age of the pole (Zhan et al., 2007) may extend from 635 to $615 \mathrm{Ma}$. In the following discussion, we use $625 \mathrm{Ma}$, the average age of the sampling strata, as the age of the pole of Zhan et al. (2007).

Concerning the paleomagnetic pole from the green colored basalts of the Baiyisi formation in the Xishankou area of Quruqtagh (Huang et al., 2005), neither fold test due to its uniform bedding nor reversal polarity has been obtained. These basalts are, in fact, metamorphosed as the chlorite can be widely observed in these rocks. Moreover, the magnetic directions isolated from these basalts are similar to those of the overlying Zhaobishan formation by this study (Table 1), which failed the fold test and are thought to be secondary (see Section 4.1.1 above). Furthermore, the AMS measurements have been made on the paleomagnetic samples from the overlying Zhaobishan Formation. The AMS results display a nearly horizontal $\mathrm{K}_{3}\left(\mathrm{D}=164.3^{\circ}\right.$, $\mathrm{I}=14.2^{\circ} \alpha_{95 \mathrm{max} / \min }=9.1^{\circ} / 5.2^{\circ}$; Fig. $\left.6 \mathrm{f}\right)$, suggesting that the magnetic fabrics must be developed after the sedimentation and the rocks have been affected by later deformation. So, it is reasonable to consider that both the Baiyisi Formation (Huang et al., 2005) and its overlaying Zhaobishan formation (Table 1) in the Xishankou area have been remagnetized and cannot be used for the Neoproterozoic period. 
Concerning the Phanerozoic poles used to establish the APWP of the Tarim block, we refer to the recent synthetic publications by Fang et al. (2006), Huang et al. (2008) and Gilder et al. (2008), with also poles published after 2008. An age-mean pole has been calculated when several poles are available for one geological period (Table 2). Combining our two paleomagnetic poles with the previously published ones, the APWP of the Tarim block was build up using the paleomagnetic poles listed in Table 2. Most of these poles satisfy at least one of the following two characters: positive fold test, both normal and reverse polarities. The paleomagnetic poles and their uncertainties are shown by black dots and their confidence ellipse, respectively, and the probable APWP is shown by the dark line in Figure 8a.

5.4 Kinematic history of the Tarim block: a long term Australia-Tarim connection

According to this new APWP, we may characterize the kinematic history of the Tarim block as following. At $\sim 800 \mathrm{Ma}$, Tarim was located at about $45^{\circ} \mathrm{N}$ with a perpendicular orientation with respect to its present shape. From the Late Neoproterozoic (Ediacarian) to Ordovician, the Tarim block moved southwards with variable velocities until ca. $18^{\circ} \mathrm{S}$. Since Ordovician, the Tarim block changed its motion direction to the north, reaching the latitude of ca. $15^{\circ} \mathrm{N}$ in Early Silurian (Sun and Huang, 2009). From this time to the Late Devonian, the paleomagnetic poles show a good consistency, implying that the Tarim block was stationary during this period. From the Late Devonian to the Late Carboniferous, a significant northward drift of Tarim is identified with also a clockwise rotation of the block. Since the Late 
Carboniferous, the poles of Tarim become stationary indicating that this block did not experience a significant movement since then (Fang et al., 2006; Gilder et al., 2008; Huang et al., 2008). Of course, cautions should be taken for this simplified kinematic story as the paleomagnetic poles are not determined for equal time intervals.

The Paleozoic paleomagnetic data from Australia have been summarized by McEhlinny et al. (2003). After a thorough assessment of Paleozoic paleomagnetic results from different localities of Australia, a coherent path with respect to that of the Gondwana supercontinent has been documented, and the corresponding Paleozoic APWP has also been established in the Northwest Africa coordinates (McEhlinny et al., 2003). For the convenience of comparison, the Australian APWP in the Northwest Africa coordinates is restored to its own ones around an Euler pole at $28.1^{\circ} \mathrm{S}, 293.2^{\circ} \mathrm{E}$ with angle of $-52.1^{\circ}$ (McEhlinny et al., 2003). The Neoproterozoic-Paleozoic APWP for Australia may join the key Neoproterozoic poles of $755 \pm 3$ Ma derived from the Mundine Well dyke swarm (MDS) of the Pilbara Craton, Western Australia (Wingate and Giddings, 2000), the Yaltipena Formation (ca. 640Ma) of the central Flinders Range of South Australia (Sohl et al., 1999; Li and Evans, 2011), the mean Elatina formations (ca. $635 \mathrm{Ma}$ ) of the central Flinders Range of South Australia (Li and Evans, 2011) and the Nuccaleena Formation (ca. 630Ma) of the Adelaide Geosyncline of South Australia (Schimidt et al., 2009; Li and Evans, 2011).

For a better comparison, Tarim was rotated into the Australian coordinates using an Euler pole at $45.9^{\circ} \mathrm{S}, 277.6^{\circ} \mathrm{E}$ with an angle of $-43.4^{\circ}$. After this rotation, these two APWPs fit well with each other from $\sim 750 \mathrm{Ma}$ to $\sim 480 \mathrm{Ma}$ (Fig. $8 \mathrm{~b}$ ), which indicates 
the connection between Tarim and Australia during this time interval. However, the $\sim 640$ - 615Ma poles of the two APWPs do not perfectly overlap. This discrepancy may be due to the poorly constrained ages of these poles, as no direct isotopic age has been obtained for the three Australian poles, and their ages were estimated by tillite comparison and stratigraphic contact (Sohl et al., 1999; Schmidt et al., 2009; Li and Evans, 2011). Nevertheless, considering the large $A_{95}$ of these poles, they are statistically indistinguishable (Fig. 8b). The Early Ordovician (480Ma) pole of Tarim overlaps well with that of Australia (Fig. 8), while both the Late Ordovician (450Ma) and the Middle Silurian (425Ma) poles are distinguished, which may indicate that these two blocks began to separate with each other during the Late Ordovician to Silurian (Fig. 8). However, the rapid break away of Tarim from Australia may occur after the Middle Silurian, as the poles begin to significantly separate and lay far away from each other since the Middle Silurian (Fig. 8).

Several reconstructions of Tarim and Australia during the Neoproterozoic have been attempted (Powell and Pisarevsky, 2002; Chen et al., 2004; Zhan et al., 2007; Li et al., 2008). Although the debate still exists about whether these two continents connected directly (Chen et al., 2004; Zhan et al., 2007) or Tarim was located at the margin of an Australia-centered continent (Powell and Pisarevsky, 2002; Li et al., 2008), both of these reconstructions placed Tarim to the northwest of Australia, and considered that Tarim and Australia displayed the same evolutional pattern from the breakup of the Rodinia supercontinent to the amalgamation of the Gondwana supercontinent (Fig. 9). The penetrative 800-750Ma mafic dykes, identified from both 
northern Tarim (Chen et al., 2004; Zhang et al., 2007) and northwestern Australia (Wingate and Giddings, 2000), suggest the connection between Tarim and Australia at least since ca. 800Ma. The tectonostratigraphic analysis from both blocks also suggests that the Tarim block was adjacent to the Kimberley region, northwestern Australia in the Neoproterozoic (Li et al., 1996). New sedimentary analysis carried out from the Sugetbrak and Qigebrak formations in the Aksu area, northwestern Tarim, suggests that the nonmarine, fluvial and lacustrine facies of the Sugetbrak formation can correlate with the upper part of the Louisa Downs and Albert Edward groups in northwestern Australia, indicating the connection between these two blocks in the Late Neoproterozoic (Turner, 2010). New researches about the basement of Tarim reveal that the unified Tarim block in the Neoproterozoic should be much larger than the present Tarim basin, as hundreds of kilometers of continental margin has subducted due to posterior continental convergence (Xu et al., 2013). In our paleogeographic reconstruction map, the same rotation transfers the Tarim to the northwest of Australia, in broad agreement with previous reconstruction (Fig. 9; Chen et al., 2004; Zhan et al., 2007; Li and Evans, 2011; Zhang et al., 2013), and during the break-up of Rodinia supercontinent, Tarim still stay close to Australia.

The timing of the separation between Tarim and Australia is still in debate, with different ages from the latest Neoproterozoic ( $\mathrm{Li}$ et al., 1996) to the Middle Paleozoic (e.g. Metcalfe, 2006, 2009, 2011). The upper Neoproterozoic succession in the Kimberley region, northwestern Australia, is unconformably overlain by the Cambrian Antrim Plateau mafic volcanics (Hanley and Wingate, 2000; Glass and 
Phillips, 2006), which were thought to represent the extensional event corresponding to the separation of Tarim from Australia (Li et al., 1996). For the Tarim part, Early Cambrian volcanic rocks were also found in the Quruqtagh area, northeast of the Tarim block (Jia et al., 2004). Meanwhile, trace element study of the phosphorite shale at the base of the Lower Cambrian in the northwestern Tarim block indicates the mafic material sources (Yu et al., 2003). Furthermore, the Cambrian strata of the Tarim block consist of phosphates and evaporites at similar stratigraphic levels to those of Australia (Metcalfe, 2006, 2009); and the same microfossil assemblages have been found from the Ordovician and Silurian successions of both the Tarim and Australia blocks (Burrett et al., 1990; Metcalfe, 2011). The deposition facies and fossil similarities from the Cambrian to Silurian indicate the connection of these two blocks in this period (Metcalfe, 2006, 2011). The separation was proposed to take place in the Early Devonian as the splitting of the Silurian Sino-Australian brachiopod province into two sub-provinces and the apparent loss of links between Tarim and Australia (Metcalfe, 2006). These paleontological observations coincide with our APWP comparison: the proximity of the Ordovician and Silurian poles, while far away from each other of the Devonian poles from two blocks (Fig. 8b). After the Silurian, Australia moved southwards to the southern hemisphere (Schmidt et al., 1987; Thrupp et al., 1991), whereas the Tarim block stayed at the low latitude position in the northern hemisphere and drifted northwards from the Devonian to Carboniferous (Li et al., 1990; Zhao et al., 1993). Taking the paleomagnetic, sedimentary and paleontology evidences into account, the hypothesis of an initial 
break-up at the Late Ordovician and a fast separation at the Late Silurian-Early Devonian between Tarim and Australia seems the most documented.

Although no consensus about the relative position between the South China block (SCB) and Australia so far (Li et al., 2008; Li and Evans, 2011; Zhang et al., 2013), the similarity in APWPs between Australia and the SCB has been described by Yang et al. (2004) based only on three poles, showing that the South China block was connected to the northwestern Australia during the Neoproterozoic until the Late Silurian-Early Devonian. The biostratigraphic study revealed that the upper T. anozos - T. conoideum assemblage of the Ediacaran Doushantuo formation in the Yangtze Gorge area can be correlated with the Ediacaran complex acritarch palynoflora (ECAP) of South and Central Australia (Liu et al., 2013). Besides, the lower Paleozoic strata of the South China block display the same depositional pattern (Metcalfe, 2006) and fossil assemblages (Burrett et al., 1990; Yao et al., 2005; Moczydlowska and Zang, 2006; Dong et al., 2009; Metcalfe, 2013) as those of Tarim and Australia. Instead of putting SCB to the northwestern Australia, Li et al., (2008) and Li and Evans, (2011) putted the SCB to the northeastern Australia to fit the "missing link model" at $750 \mathrm{Ma}$ and considered that the SCB had moved northeast away from Australia at ca. 635Ma (Position 1 of SCB in Fig. 9; see also Fig. 2c in Li and Evans, 2011). Moreover, Zhang et al., (2013) had recently published their new paleomagnetic results from the Nantuo formation of SCB $(636.3 \pm 4.9 \mathrm{Ma})$ and show a relatively high paleolatitude of SCB. Combining geologic and paleomagnetic data, they concluded that nevertheless the SCB was closely situated to the north of 
Australia, and the direct SCB-northwestern Australia connection at the Early Cambrian-Early Devonian, had not formed at the time of ca. $635 \mathrm{Ma}$ (Position 2 of SCB in Fig. 9; see also Fig. 10 in Zhang et al., 2013). Consequently, the kinematic history between SCB and Australia is still controversial; more results are needed to improve the understanding.

\section{Conclusions}

New paleomagnetic study is performed on the Neoproterozoic strata from the Quruqtagh and Yecheng areas in the northeastern and southwestern Tarim block, respectively. Magnetic mineralogical analyses show that titanium-poor magnetite and hematite are the principal magnetic carriers. The directional analyses reveal both primary and secondary magnetizations. Among the 64 studied sites, except the viscous and dispersed sites due to the too weak NRM (10 sites), 16 sites near the active tectonic zone present a high anisotropic degree, vertical magnetic foliation with no tectonically interpretable magnetic directions; 26 sites show the effect of remagnetization. However, 6 sites from the ca. 635Ma Tereeken Formation cap carbonate, and 6 sites from the 615Ma Zhamoketi basaltic andesite from the Quruqtagh area present stable and probably primary magnetic remanences with a weak anisotropic degree, and either a positive fold test for the former or a consistent direction with previous results for the latter. Therefore, two Neoproterozoic paleomagnetic poles were calculated at: $\lambda=27.6^{\circ} \mathrm{N}, \varphi=140.4^{\circ} \mathrm{E}, \mathrm{dp}=8.8^{\circ}, \mathrm{dm}=11.1^{\circ}$, and $\lambda=-4.9^{\circ} \mathrm{N}, \varphi=146.7^{\circ} \mathrm{E}, \mathrm{dp}=3.0^{\circ}, \mathrm{dm}=5.2^{\circ}$ for the Tereeken and Zhamoketi 
formations, respectively. Combining these two poles with the paleomagnetic poles previously reported from Tarim, a new APWP from the Neoproterozoic to the Present has been built for the Tarim block. The comparison between the APWPs from Tarim and Australia implicates that there is a long-term, from at least the Neoproterozoic to the Middle Silurian, Australia-Tarim connection and/or they share the same kinematic evolution. The Tarim block probably began to break away from northwestern Australia since the Late Ordovician and the final separation occurred at the Late Silurian-Early Devonian.

\section{Acknowledgements}

This study was supported by grants from the National Natural Science Foundation of China ( $\mathrm{N}^{\circ} 40972126$ and 41121062). We appreciate the detailed and constructive comments on the first version of manuscript by two anonymous reviewers. We also present our thanks to Jinyou He, Wei Wei and Qinlong Tong for their field assistance.

\section{Reference:}

Bai, Y.H., Chen, G.L., Sun, Q.G., Sun, Y.H., Li, Y.A., Dong, Y.J., Sun, D.J. 1987. Late Paleozoic polar wander path for the Tarim platform and its tectonic significance. Tectonophysics 139, 145-153.

Brookfield, M.E., 1994. Problems in applying preservation facies and sequence models to the Sinian (Neoproterozoic) glacial sequences in Australia and Asia. Precambrian Res. 70, 143-147. 
Burrett, C., Long, J., Stait, B., 1990. Early-Middle Palaeozoic biogeography of Asian terranes derived from Gondwana. Geol. Soc. London, Memoirs 12, 163-174.

Charreau, J., Gilder, S., Chen, Y., Dominguez, S., Avouac, J.P., Sen, S., Jolivet, M., Li,Y.A., Wang, W.M., 2006. Magnetostratigraphy of the Yaha section, Tarim Basin (China): $11 \mathrm{Ma}$ acceleration in erosion and uplift of the Tianshan Mountains, Geology, 34, 181-184.

Charvet, J., Shu, L.S., Laurent-Charvet, S., Wang, B., Faure, M., Cluzel, D., Chen, Y., De Jong, K., 2011. Palaeozoic tectonic evolution of the Tianshan belt, NW China. Sci. China Earth Sci. 56(2), 166-184.

Chen, J., Burbank, D.W., Scharer, K.M., Sobel, E., Yin, J.H., Rubin, C., Zhao, R.B., 2002. Magnetochronology of the Upper Cenozoic strata in the Southwestern Chinese Tian Shan: Rates of Pleistocene folding and thrusting, Earth Planet. Sci. Lett. 195, 113-130.

Chen, X., Shu, L., Santosh, M., 2011. Late Paleozoic post-collisional magmatism in the Eastern Tianshan Belt, Northwest China: New insights from geochemistry, geochronology and petrology of bimodal volcanic rocks. Lithos 127, 581-598.

Chen Y., Cogné, J.P., Courtillot, V., New paleomagnetic poles from the Tarim Basin, Northwestern China. Earth Planet. Sci. Lett. 114, 17-38, 1992.

Chen, Y., Cogné, J.P., Courtillot, V., Avouac, J.Ph., Tapponnier, P., Buffetaut, E., Wang, G., Bai, M., You, H., Li, M., Wei, C., 1991. Paleomagneitc study of Mesozoic continental sediments along the northern Tien Shan (China) and heterogeneous strain in central Asia. J. Geophys.Res. 96, 4065-4082. 
Chen, Y., Courtillot, V., Cogné, J.P., Besse, J., Yang, Z., Enkin, R., 1993. The configuration of Asia prior to the collision of India Cretaceous paleomagnetic constraints. J. Geophys. Res. 98, 21937-21941.

Chen, Y., Xu, B., Zhan, S., Li, Y.A., 2004. First mid-Neoproterozoic paleomagnetic results from the Tarim Basin (NW China) and their geodynamic implications. Precambrian Res. 133, 271-281.

Chen, Y., Gilder, S., Halim, N.M., Cogné, J.P., Courtillot, V., 2002. New paleomagnetic constraints on central Asian kinematics: Displacement along the Altyn Tagh fault and rotation of the Qaidam Basin, Tectonics 21(5), 1042, doi:10.1029/2001TC901030.

Cheng, G. L., Y. H. Bai, and Y. A. Li (1983), Paleomagnetism of the Lower Permian in the Wushi-Aksu area of Xinjiang, Seimol. Geol., 4, 12.

Cheng, R., Wang, P., Sun, X., Bai, Y., 2006. Sequence stratigraphy and sea level changes of Ordovician in Kuruktag, Xinjiang. Geotectonica et Metallogenia, 30(3), 283-293 (in Chinese with English abstract).

Cogné, J.P., 2003. A MacintoshTM application for treating paleomagnetic data and making plate reconstructions. Geochem. Geophys. Geosyst. 4 (1). doi:10.1029/2001GC000227.

Condon, D., Zhu, M.Y., Bowring, S., Wang, W., Yang, A.H., Jin, Y.G., 2005. U-Pb Ages from the Neoproterozoic Doushantuo formation, China. Science 308, 95-98.

Dong, L., Xiao, S., Shen, B., Zhou, C., Li, G., Yao, J., 2009. Basal Cambrian microfossils from the Yangtze Gorges area (South China) and the Aksu area 
(Tarim Block, northwestern China). J. Paleont. 83(1), 30-44.

Enkin, R.J., 2003. The direction-correction tilt test: an all-purpose tilt/fold test for paleomagnetic studies. Earth Plant. Sci. Lett. 212, 151-166.

Enkin, R.J., Chen, Y., Courtillot, V., Besse, J., Xing, L., Zhang, Z., Zhuang, Z., Zhang, J., 1991. A Cretaceous pole from South China, and the Mesozoic hairpin turn of the Eurasian APWP. J. Geophys.Res. 96, 4007-4027.

Fang, D.J., Jin, G.H., Jiang, L.P., Wang, P.Y., Wang, Z.L., 1996. Paleozoic paleomagnetic results and the tectonic significance of Tarim palte. Acta Geohpysica Sinica, 39(4), 522-532 (in Chinese with English abstract).

Fang, D.J., Wang, P.Y., Shen, Z.Y., Tan, X.D., 1998. Paleomagnetic results and Phanerozoic apparent polar wandering path of Tarim block. Sci. China Ser. D 41(Suppl.), 105-112.

Fang, D.J., Shen, Z.Y., Tan, X.D., Chen, H.L., 2006. Paleomagnetism of Tarim Basin and the Plate motion. Zhejiang University Press, Hangzhou, 1-364 (in Chinese with English abstract).

Fisher, R., 1953. Dispersion on a sphere, Proc. R. Soc. London, Ser. A, 217, 295-305.

Gao, J., Long, L., Klemd, R., Qian, Q., Liu, D., Xiong, X., Su, W., Liu, W., Wang, Y., Yang, F., 2009. Tectonic evolution of the South Tianshan orogen and adjacent regions, NW China: geochemical and age constraints of granitoid rocks. Int. J. Earth Sci. 98, 1221-1238.

Gao, J.Z., Chen, J.B., Lu, S.N., Peng, C.W., Qin, Z.Y., 1993. The Precambrian Geology in northern Xinjiang. Precambrian Geology No. 6. Geological 
Publishing House, Beijing, pp. 1-171 (in Chinese).

Gao, Z., and Qian, J., 1985. Sinian glacial deposits in Xinjiang, Northwest China. Precambrian Res. 29, 143-147.

Gao, Z.J., Wang, W.Y., Peng C.W., Li, Y.A., Xiao, B., 1985. The Sinian System of Xinjiang. Urumqi. Xinjiang Peoples's Publishing House, 35-93 (in Chinese with English abstract).

Gilder, S. A., Zhao, X., Coe, R. S., Meng, Z.F., Courtillot, V., Besse, J., 1996. Paleomagnetism and tectonics of the southern Tarim Basin, northwestern China. J.Geophys. Res. 126, 303-313.

Gilder, S., Chen, Y., Cogné, J.P., Tan, X.D., Courtillot, V., Sun, D.J., Li, Y.A., 2003. Paleomagnetism of Upper Jurassic to Lower Cretaceous volcanic and sedimentary rocks from the western Tarim Basin and implications for inclination shallowing and absolute dating of the M-0 (ISEA?) chron. Earth Planet. Sci. Lett. $206,587-600$

Gilder, S.A., Gomez, J., Chen, Y., Cogné, J.P., 2008. A new paleogeographic configuration of the Eurasian landmass resolves a paleomagnetic paradox of the Tarim Basin (China). Tectonics 27, TC1012, doi:10.1029/2007TC002155.

Glass, L.M., Phillips, D., 2006. The Kalkarindji continental flood basalt province: a new Cambrian large igneous province in Australia with possible links to faunal extinctions. Geology 34, 461-646.

Gradstein, F.M., Ogg, J.G., Smith, A.G., Bleeker, W., Lourens, L.J., 2004. A new geological time scale, with special reference to Precambrian and Neogene. 
Episodes27(2), 83-100.

Gregory, L.C., Meert, J.G., Bingen, B., Pandit, M.K., Torsvik, T.H., 2009. Paleomagnetism and geochronology of the Malani Igneous Suite, Northwest India: Implications for the configuration of Rodinia and the assembly of Gondwana. Precambrian Res. 170, 13-26.

Hanley, L.M., Wingate, M.T.D., 2000. SHRIMP zircon age for an Early Cambrian dolerite dyke: an intrusive phase of the Antrim Plateau Volcanics of northern Australia. Aus. J. Earth Sci. 47, 1029-1040.

He, X.B., Xu, B., Yuan, Z.Y., 2007. C-isotope composition and correlation of the Upper Neoproterozoic in Keping area, Xinjiang. Chi. Sci. Bull. 52(4), 504-511.

Huang, B.C., Xu, B., Zhang, C.X., Li, Y.A., Zhu, R.X., 2005. Paleomagnetism of the Baiyisi volcanic rocks (ca. $740 \mathrm{Ma}$ ) of Tarim, Northwest China: A continental fragment of Neoproterozoic Western Australia? Precambrian Res. 142, 83-92.

Huang, B. C., Piper, J.D.A. Peng, S.T. Liu, T., Li, Z., Wang, Q.C., Zhu, R.X. 2006. Magnetostratigraphic study of the Kuche Depression, Tarim Basin, and Cenozoic uplift of the Tian Shan Range, Western China, Earth Planet. Sci. Lett. 251, 346-364, doi:10.1016/j.eps1.2006.09.020.

Huang, B.C., Zhou, Y.X., Zhu, R. X., 2008. Discussions on Phanerozoic evolution and formation of continental China, based on paleomagnetic studies. Earth Science Frontiers, 15(3), 348-358.

Jelínek, V., 1978. Statistical processing of anisotropy of magnetic susceptibility measured on groups of specimen, Stud. Geofyz. Geodet., 22, 50-62. 
Jia, C.Z., Zhang, S.B., Wu, S.Z., 2004. Stratigraphy of the Tarim Basin ans Adjacent areas. China Science Publishing House, Beijing, 1-1063 (in Chinese with English abstract).

Kirschvink, J.L., 1980. The least squares line and the analysis of paleomagnetic data. Geophys. J. R. Astro. Soc. 62, 699-718.

Knoll, A.H., 2000. Learning to tell Neoproterozoic time. Precambrian Res. 100, 3-20.

Lee, J., 1991. Incremental 40Ar/39Ar thermochronology of mylonitic rocks from the northern Snake Range, Nevada. Tectonics 10, 77-100.

Li, Y.A., Chen, Y., Cogne, J.P., Gilder, S., Sun, D.J., 2003. Paleomagnetic study of the Late Jurassic at the southwestern margin of Tarim. Acta Geologica Sinica, 77(2), 151-157 (in Chinese with English abstract).

Li, Y.P., McWilliams, M., Cox, A., Shrarps, R., Li, Y., Gao, Z., Zhang, Z., Zhai, Y., 1988a. Late Permian Paleomagnetic pole from dikes of the Tarim craton, China. Geology 16, 275-278.

Li, Y.P., Zhang, Z., McWilliams, M., Sharps, R., Zhai, Y., Li, Y.A., Li, Q., Cox, A., 1988b. Mesozoic paleomagnetic results of the Tarim Craton: Tertiary relative motion between China and Siberia? Geophysical Research Letters, 15, 217-220.

Li, Y.P., McWilliams, M., Sharps, R., Li, Y.A., Gao, Z.J., 1990. A Devonian paleomagnetic pole from red beds of the Tarim Block, China. J. Geophys.Res. 98, 185-198.

Li, Y.P., Li, Y., Sharps, R., McWilliams, M., Gao, J., 1991. Sinian paleomagnetic results from the Tarim block, western China. Precambrian Res. 49, 61-71. 
Li, Z.X., and Evans, D.A.D., 2011. Late Neoproterozoic $40^{\circ}$ intraplate rotation within Australia allows for a tighter-fitting and longer-lasting Rodinia. Geology 39, $39-42$.

Li, Z.X., Evans, D.A.D., Zhang, S., 2004. A 90॰ spin on Rodinia: possible causal links between the Neoproterozoic supercontinent, superplume, true polar wander and low-latitude glaciation. Earth Planet. Sci. Lett. 220, 409-421.

Li, Z.X., Li, X.H., Kinny, P.D., Wang, J., 1999. The breakup of Rodinia: did it start with a mantle plume beneath South China? Earth Planet. Sci. Lett. 173, 171-181.

Li, Z.X., and Powell, C.M., 2001. An outline of the palaeogeographic evolution of the Australasian region since the beginning of the Neoproterozoic. Earth-Sci. Rev. $53,237-277$.

Li, Z.X., Zhang, L., Powell, C.McA., 1996. Positions of the East Asian cratons in the Neoproterozoic supercontinent Rodinia. Aus. J. Earth Sci. 43, 593-604.

Li, Z.X., Bogdanova, S.V., Collins, A.S.,Davidson, A.,DeWaele, B., Ernst, R.E., Fitzsimons, I.C.W., Fuck, R.A., Gladkochub, D.P., Jacobs, J., Karlstrom, K.E., Lu, S., Natapov, L.M., Pease, V., Pisarevsky, S.A.,Thrane, K., Vernikovsky,V., 2008. Assembly, configuration, and break-up history of Rodinia: a synthesis. Precambrian Res. 160, 179-210.

Liu, P., Yin, C., Chen, S., Tang, F., Gao, L., 2013. The biostratigraphic succession of acanthomorphic acritarchs of the Ediacaran Doushantuo Formation in the Yangtze Gorges area, South China and its biostratigraphic correlation with Australia. Precambrian Res. 225, 29-43. 
Long, X.P., Yuan, C., Sun, M., Zhao, G.C., Xiao, W.J., Wang, Y.J., Yang, Y.H., Hu, A.Q., 2010. Archean crustal evolution of the northern Tarim craton, NW China: Zircon U-Pb and Hf isotopic constraints. Precambrian Res.180, 272-284.

Lu, S., Li, H., Zhang, C., Niu, G., 2008. Geological and geochronological evidence for the Precambrian evolution of the Tarim Craton and surrounding continental fragments. Precambrian Res. 160, 94-107.

Ma, S., Wang, Y., Fang, X., 1991. Basic characteristics of Proterozoic Eonothem as a table cover on Northern slope of Western Kunlun Mountain. Xinjiang Geol. 9, 59-71(in Chinese with English abstract).

Macouin, M., Besse, J., Ader, M., Gilder, S.,Yang, Z., Sun, Z., Agrinier, P., 2004. Combined paleomagnetic and isotopic data from the Doushantuo carbonates South China: implications for the "snowball Earth" hypothesis. Earth Planet. Sci. Lett. 224, 387-398.

Maluski, H., Rajlich, P., Matte, P., 1993. 40Ar/39Ar dating of the inner Carpathians Variscan basement and Alpine mylonitic overprinting. Tectonophysics 223, $313-337$.

Matte, P., Tapponnier, P., Arnaud, N., Bourjot, L, Avouac, J.P., Vidal, P., Liu, Q., Pan, Y., Wang, Y., 1996. Tectonics of Western Tibet, between the Tarim and the Indus. Earth Planet. Sci. Lett. 142, 311-330.

McElhinny, M.W., 1964. Statistical significance of the fold test in paleomagnetism. Geophys. J. Royal Astr. Soc. 8, 33-40.

McFadden, P. L., Ma, X. H., McElhinny, M. W., Zhang, Z. K., 1988. Permo-Triassic 
magnetostratigraphy in China: northern Tarim. Earth Planet. Sci. Lett. 87, 152-160.

McFadden, P. L., and McElhinny, M.W., 1988. The combined analysis of remagnetization circles and direct observations in palaeomagnetism. Earth Plant. Sci. Lett. 87, 161-172.

McFadden, P. L., and McElhinny, M.W., 1990. Classification of the reversal test in palaeomagnetism. Geophys. J. Int. 103, 725-729.

Meert, J.G., and Torsvik, T.H., 2003. The making and unmaking of a supercontinent: Rodinia revisited. Tectonophysics 375, 261-288.

Meng, Z. F., Deng, Y. S., Ding, Z. H., Zheng, Y.P., Li, Y.A., Sun, D.J., 1998. New paleomagnetic results from Ceno-Mesozoic volcanic rocks along southern rim of the Tarim Basin, China, Sci. in China, Ser. D 41(supp.), 91-104.

Metcalfe, I., 2006. Palaeozoic and Mesozoic tectonic evolution and palaeogeography of East Asian crustal fragments: The Korean Peninsula in context. Gondwana Res. 9, 24-46.

Metcalfe, I., 2009. Late Palaeozoic and Mesozoic tectonic and palaeogeographical evolution of SE Asia. In: Buffetaut, E., Cuny, G., Le Loeuff, J., Suteethorn, V. (eds), Late Palaeozoic and Mesozoic Ecosystems in SE Asia. Geol. Soc. London, Spec. Publ., 315, 7-23.

Metcalfe, I., 2011. Palaeozoic-Mesozoic history of South Asia. In: Hall, R., Cottam, M., Wilson, M.E.J. (eds), The SE Asian Gateway: History and Tectonics of the Australia-Asia Collision. Geol. Soc. London, Spec. Publ., 355, 7-35. 
Metcalfe, I., 2013. Gondwana dispersion and Asian accretion: Tectonic and palaeogeographic evolution of eastern Tethys, J. Asian Earth Sci., doi: http://dx.doi.org/10.1016/j.jseaes

Moczydlowska, M., and Zang, W.L., 2006. The Early Cambrian acritarch Skiagia and its significance for global correlation. Palaeoworld 15, 328-347.

Nie, S. Y., 1991. Paleoclimatic and paleomagnetic constraints on the Paleozoic reconstruction of south China, north China and Tarim. Tectonophysics 196, 279-308.

Powell, C.M., and Pisarevsky, S.A., 2002. Late Neoproterozoic assembly of East Gondwana. Geology, 30, 3-6.

Radhakrishnamurty,C., and Likhite, S.D., 1970. Hopkinson effect, blocking temperature and Curie point in basalts. Earth Plant. Sci. Lett. 7, 389-396.

Schmidt, P.W., Embleton, B.J.J., Palmer, H.C., 1987. Pre- and post-folding magnetizations from the early Devonian Snowy River Volcanics and Buchan Caves Limestone, Victoria. Geophys. J. R. Astr. Soc. 91, 155-170.

Schmidt, P.W., Williams, G.E., McWilliams, M.O., 2009. Palaeomagnetism and magnetic anisotropy of late Neoproterozoic strata, South Australia: Implications for the palaeolatitude of late Cryogenian glaciation, cap carbonate and the Ediacaran System. Precambrian Res. 174, 35-52.

Sharps, R., McWilliams, M., Li, Y.P., Cox, A., Zhang, Z.K., Zhai, Y.J., Gao, Z.J., Li, Y.A., Li, Q. 1989. Lower Permian paleomagnetism of the Tarim block, northwestern China. Earth Planet. Sci. Lett. 92, 275-291. 
Shu, L.S., Deng, X.L., Zhu, W.B., Ma, D.S., Xiao, W.J., 2011. Precambrian tectonic evolution of the Tarim Block, NW China: New geochronological insights from the Quruqtagh domain. J. Asian Earth Sci. 42, 774-790.

Sohl, L.E., Christie-Blick, N., Kent, D.V., 1999. Paleomagnetic polarity reversals in Marinoan (ca. 600Ma) glacial deposits of Australia: Implications for the duration of low-latitude glaciation in Neoproterozoic time. Geolo. Soc. Am. Bull. 111, $1120-1139$.

Sun, L.S., and Huang, B.C., 2009. New paleomagnetic result for Ordovician rocks from the Tarim Block, Northwest China and its tectonic implications. Chinese Journal of Geophysics, 52(7), 1836-1848 (in Chinese with English abstract).

Tan, X.D., Kodama,K.P., Chen,H.L., Fang, D.J., Sun,D.J., Li,Y.A., 2003. Paleomagnetism and magnetic anisotropy of Cretaceous red beds from the Tarim Basin, northwest China: Evidence for a rock magnetic cause of anomalously shallow paleomagnetic inclinations from central Asia, J. Geophys. Res., 108(B2), 2107, doi:10.1029/2001JB001608.

Tang L., 1997. An approach to major tectogenesis of Tarim Basin. Experimental Petroleum Geology, 19 (2), 108-114 (in Chinese with English abstract).

Thrupp, G.A., Kent, D.V., Schmidt, P.W., Powell, C.M., 1991. Palaeomagnetism of red beds of the Late Devonian Worange Point Formation, SE Australia. Geophys. J. Int. 104, 179-201.

Tong Q L, Wei W, Xu B. 2013. Neoproterozoic sedimentary facies and glacial periods in the southwest of Tarim Block. Science China: Earth Sciences, 56, 901-912, 
doi: 10.1007/s11430-013-4595-4.

Torsvik, T.H., Carter, L.M., Ashwal, L.D., Bhushan, S.K., Pandit, M.K., Jamtveit, B., 2001. Rodinia refined or obscured: palaeomagnetism of the Malani igneous suite (NW India). Precambrian Res. 108, 319-333.

Turner, S.A., 2010. Sedimentary record of Late Neoproterozoic rifting in the NW Tarim Basin, China. Precambrian Res. 181, 85-96.

Wang, A., Zhang, C., Zhao, Y., Guo, K., Dong, Y., 2004. Depositional types of lower part of Nanhuan System on the northern margin of southwest Tarim and their tectonic significance. J. Stratigr. 28(3), 248-256 (in Chinese with English abstract).

Wang, B., Chen, Y., Zhan, S., Shu, L.S., Faure, M., Cluzel, D., Charvet, J., Laurent-Charvet, S., 2007. Primary Carboniferous and Permian paleomagnetic results from the Yili Block (NW China) and their implications on the geodynamic evolution of Chinese Tianshan Belt. Earth Planet. Sci. Lett. 263, 288-308.

Wang, B., Faure, M., Shu, L.S., Cluzel, D., Charvet, J., De Jong, K., Chen, Y., 2008. Paleozoic tectonic evolution of the Yili Block, western Chinese Tianshan. Bull. Soc. Geol. Fr., 179, 483-490.

Wang, Y., Lu, S., Gao, Z., Lin, W., Ma, G., 1981. Sinian tillites of China. In: Hambrey, M.J., and Harland, W. B. (eds.), Earth's Pre-Pleistocene glacial record. Cambridge, pp. 386-401.

Wen, B., Li Y.X., Zhu, W., 2013. Paleomagnetism of the Neoproterozoic diamictites 
of the Qiaoenbrak formation in the Aksu area, NW China: Constraints on the paleogeographic position of the Tarim Block. Precambrian Res. 226, 75-90.

Wingate, M.T.D., and Giddings, J.W., 2000, Age and palaeomagnetism of the Mundine Well dyke swarm, Western Australia: Implications for an Australia-Laurentia connection at 755 Ma: Precambrian Res. 100, 335-357, doi: 10.1016/S0301-9268(99)00080-7.

Wingate, M.T.D., and Giddings, J.W., 2000. Age and palaeomagnetism of the Mundine Well dyke swarm, Western Australia: implications for an Australia-Laurentia connection at 755 Ma. Precambrian Res. 100, 335-357.

Xiao, S., Bao, H., Wang, H., Kaufman, A.J., Zhou, C., Li, G., Yuan, X., Ling, H., 2004. The Neoproterozoic Quruqtagh Group in eastern Chinese Tianshan: evidence for a post-Marinoan glaciation. Precambrian Res. 130, 1-26.

Xiao, S., Bao, H.,Wang, H., Kaufman, A.J., Zhou, C., Li, G., Yuan, X., Ling, H., 2004. The Neoproterozoic Quruqtagh Group in eastern Chinese Tianshan: evidence for a post-Marinoan glaciation. Precambrian Res. 130, 1-26.

XJBGMR (Xinjiang Bureau of Geology and Mineral Resources), 1993. Regional Geology of Xinjiang Uygur Autonomous Region. Geological Publishing House, Beijing, pp. 8-33 (in Chinese).

Xu, B., Jian, P., Zheng, H.F., Zou, H.B., Zhang, L.F., Liu, D.Y., 2005. U-Pb zircon geochronology and geochemistry of Neoproterozoic volcanic rocks in the Tarim Block of northwest China: implications for the breakup of Rodinia supercontinent and Neoproterozoic glaciations. Precambrian Res. 136, 107-123. 
Xu, B., Xiao, S.H., Zou, H.B., Chen, Y., Li, Z.X., Song, B., Liu, D.Y., Zhou, C.M., Yuan, X.L., 2009. SHRIMP zircon U-Pb age constraints on Neoproterozoic Quruqtagh diamictites in NWChina. Precambrian Res. 168, 247-258.

Xu, B., Zou, H., Chen, Y., He, J., Wang, Y., 2013. Basalts from Sugetbrak, the northwestern Tarim Block, northwest China: Geochronology, geochemistry and implications for Rodinia breakup and ice age during the Late Neoproterozoic. Precambrian Res., accepted .

Xu, Z.-Q., He, B.-Z., Zhang, C.-L., Zhang, J.-X.,Wang, Z.-M., Cai, Z.-H., 2013. Tectonic framework and crustal evolution of the Precambrian basement of the Tarim Block inNWChina: new geochronological evidence from deep drilling samples, Precambrian Research, 235, 150-162.

Yang, Z.Y., Sun, Z.M., Yang, T.S., Pei, Y.L., 2004. A long connection (750-380 Ma) between South China and Australia: paleomagnetic constraints. Earth Planet. Sci. Lett. 220, 423-434.

Yao, J., Xiao, S., Yin, L., Li, G., Yuan, X., 2005. Basal Cambrian microfossils from the Yurtus and Xishanblaq formations (Tarim, north-west China): Systematic revision and biostratigraphic correlation of Micrhystridium-like acritarchs from China. Palaeontology, 48:687-708.

Yong, W., Zhang, L., Hall, C.M., Mukasa, S.B., Essene, E.J., 2012. The 40Ar/39Ar and $\mathrm{Rb}-\mathrm{Sr}$ chronology of the Precambrian Aksu blueschists in western China. J. Asian Earth Sci., http://dx.doi.org/10.1016/j.jseaes.2012.05.024

Yu, B., Chen, J., Li, X., Lin, C., 2003. Geochemistry of black shale at the bottom of 
the Lower Cambrian in Tarim Basin and its significance for lithosphere evolution. Sci. Chi. (Ser. D) 46 (5), 498-507.

Zhan, S., Chen, Y., Xu, B., Wang, B., Faure, M., 2007. Late Neoproterozoic paleomagnetic results from the Sugetbrak Formation of the Aksu area, Tarim basin (NW China) and their implications to paleogeographic reconstructions and the snowball Earth hypothesis, Precambrian Res. 154, 143-158.

Zhang, C., Yang C., Shen, J., Zhao, Y., Wang, A., Dong, Y., Guo, K., 2003. Zircon SHRIMP age of Neoproterozoic Gneissoid Granites in the west Kunlun and its significance. Geol. Rev. 49(3), 239-244(in Chinese with English abstract).

Zhang, C.L., Li, H.K., Santosh, M., Li, Z.X., Zou, H.B., Wang, H., Ye, H., 2012 a. Precambrian evolution and cratonization of the Tarim Block, NW China: Petrology, geochemistry, $\mathrm{Nd}$-isotopes and $\mathrm{U}-\mathrm{Pb}$ zircon geochronology from Archaean gabbro-TTG-potassic granite suite and Paleoproterozoic metamorphic belt. J. Asian Earth Sci. 47, 5-20.

Zhang, C.L., Zou, H.B., Li, H.,., Wang, H.Y., 2012b. Tectonic framework and evolution of the Tarim Block in NW China. Gondwana Res. doi:10.1016/j.gr.2012.05.009

Zhang, C.L., Li, Z.X., Li, X.H., Ye, H.M., 2009. Neoproterozoic mafic dyke swarms at the northern margin of the Tarim Block, NW China: Age, geochemistry, petrogenesis and tectonic implications. J. Asian Earth Sci. 35, 167-179.

Zhang, C.L., Li, X.H., Li, Z.X., Lu, S.N., Ye, H.M., Li, H.M., 2007. Neoproterozoic mafic-ultramafic-carbonatite complex and granitoids in Quruqtagh of 
northeasternTarim Block, western China: geochronology, geochemistry and tectonic implications. Precambrian Res. 152, 149-169.

Zhang, C.L., Ye, H.M., Wang, A.G., Guo, K.Y., Dong, Y.G., 2004. Geochemistry of the Neoproterozoic diabase and basalt in South of Tarim plate: Evidence for the Neoproterozoic breakup of the Rodinia super-continent in south of Tarim. Acta Petrol. Sin. 20(3), 473-482 (in Chinese with English abstract).

Zhang, S., Evans, D.A.D., Li, H., Wu, H., Jiang, G., Dong, J., Zhao, Q., Raub, T., Yang, T., 2013. Paleomagnetism of the late Cryogenian Nantuo Formation and paleogeographic implication for the South China Block. Journal of Asian Earth Science, 72, 164-177.

Zhang, Z.K., Li, Y.A., Li, Q., Zhai, Y.J., Li, Y.P., McWilliams, M., Cox, A., Sharps, R., 1989. Paleomagnetic results of Jurassic-Cretaceous in the Tarim. Seismology and Geology, 34(3), 343-354 (in Chinese with English abstract).

Zhao, X., Coe, R., Wu, H., Zhao, Z., 1993. Silurian and Devonian paleomagnetic poles from North China and implications for Gondwana. Earth Planet. Sci. Lett. $117,497-506$.

Zhu, M.Y., and Wang, H.F., 2012. Neoproterozoic glaciogenic diamictites of the Tarim Block, NW China. in: Arnaud, E., Halverson, G. P. \& Shields-Zhou, G. (eds) The Geological Record of Neoproterozoic Glaciations. Geol. Soc. London, Mem., 36, 367-378.

Zhu, R.X., Yang, Z.Y., Wu, H.N, Ma, X.H., Huang, B.C, Meng, Z.F., Fang, D.J., 1998. Paleomagnetic apparent polar wander paths and movement for China main 
continental blocks during Phanerozoic. Sci. in China, Ser. D 28(Suppl.), 1-16.

Zijderveld, J.D.A., 1967. Demagnetization of rocks: analysis of results. In: Collision, D.W., Creer, K.M., Runcorn, S.K. (Eds.), Methods in Paleomagnetism, pp. $254-286$ 
Table and figure captions

Table 1. Summarized paleomagnetic sampling and measurement results of this study. Abbreviations: Lith, lithology; Slong/Slat, longitude and latitude of sampling site; $\mathrm{n} / \mathrm{N}$, number of samples used to calculate mean direction/number of demagnetized samples; $\mathrm{N}, \mathrm{R}$ and $\mathrm{M}$, magnetic normal, reversal and mixed polarities, respectively; Dg, Ig Ds, Is, declination and inclination in geographic and stratigraphic coordinates, respectively; $\mathrm{k}$, the precision parameter; $\alpha_{95}$, radius that mean direction lies within $95 \%$ confidence; $\lambda / \varphi$, latitude and longitude of paleomagnetic pole; $\mathrm{dp} / \mathrm{dm}$, oval of $95 \%$ confidence for the paleomagnetic pole. PEF, Present Earth Field.

Table 2. Paleomagnetic poles for the Tarim bock from the Neoproterozoic to Present.

Abbreviations: $S$, the number of the sites; $N$, number of localities (L), sites (S) or samples (s) used to determine pole; Slong/Slat, longitude and latitude of sampling site; Plat/Plong, latitude and longitude of paleomagnetic pole; dp/dm, oval of $95 \%$ confidence for the paleomagnetic pole; $\mathrm{A}_{95}$, radius that mean direction lies within 95\% confidence; N+R, Normal and reversal polarities; FT, fold test; RT, reversal test.

Poles with * were used to build the Apparent Polar Wonder Path of Tarim. No mean pole was calculated for Late Jurassic because the three published Late Jurassic poles are not consistent. 

Figure 1. (a), Schematic tectonic map of China showing the three major Precambrian blocks. (b), Sketch map of the Tarim block and adjacent areas showing the Precambrian geology and surrounding orogens (after Lu et al., 2008).

Figure 2. (a) Simplified geologic map of the Heishan-Zhaobishan area showing the paleomagnetic sampling details. The black lines show major faults. (b) Simplified geologic map of the Qiakelikemake valley area showing the paleomagnetic sampling location (modified after Zhu and Wang, 2011). (c) Stratigrsphic column of the Quruqtagh area (modified after Xu et al, 2005, 2009), showing the sampling layers. (d) Succession of the section in the Qiakelikemake valley area showing the paleomagnetic sampling details as well as the bedding attitudes of the Kelixi Formation.

Figure 3. Magnetic mineralogical analyses. Isothermal magnetization measurements (IRM), thermal magnetic experiments (Curie temperature) and the magnetic hysteretic curve of each formation are presented.

Figure 4. Typical orthogonal vector plots (Zijderveld, 1967). Directions are plotted in in-situ coordinates. Black/white circles represent vector endpoints projected onto the horizontal/vertical plane. Numbers on the plots indicate particular temperature steps. NRM: natural remanent magnetization. 
Figure 5. Equal-area projection of mean-site directions in in-situ (IS) and tilt-corrected (TC) coordinates for each formation. Projections are shown in pairs, the left projection is IS coordinates and the right one is in TC coordinates. For the Tereeken and Zhamoketi formations, low temperature components (LTC) are also plotted to distinguish the high temperature components (HTC). Stars show the average of sites, solid squares represent normal polarity while hollow squares represent reversal polarity.

Figure 6. Results of Anisotropy of Magnetic Susceptibility (AMS) measurements. (a) and (b), plots of anisotropy degree $\left(\mathrm{P}_{\mathrm{J}}\right)$ vs shape parameter $(\mathrm{T})$ of magnetic susceptibility for the samples of the Quruqtagh and Yecheng areas, respectively. Legend for Quruqtagh area (a): solid circle, Zhamoketi Fm. from Heishan-Zhamoketi area; hollow circle, Zhamoketi Fm. from Xishankou area; cross, Altungol Fm.; solid square, Tereeken Fm.; solid triangle, Zhamoketi Fm.; solid pentagon, Shuiquan Fm.; solid star, Hancalchough Fm. (c), (d), (e) and (f), Stereoplot of K1 and K3 directions of the samples from the Tereeken, Zhamoketi, Kelixi formations, and Zhaobishan formation in Xishankou area. $K_{1}$ and $K_{3}$ are the magnetic lineation and pole of magnetic foliation; $\mathrm{P}_{\mathrm{J}}=$ $\exp \left\{2\left[\left(\ln \mathrm{K}_{1}-\ln \mathrm{K}_{\mathrm{m}}\right)^{2}+\left(\ln \mathrm{K}_{2}-\ln \mathrm{K}_{\mathrm{m}}\right)^{2}+\left(\ln \mathrm{K}_{3}-\ln \mathrm{K}_{\mathrm{m}}\right)^{2}\right]^{1 / 2}\right\}, \quad$ and $\quad \mathrm{T}=$ $\left.2 \ln \left(\mathrm{K}_{2} / \mathrm{K}_{3}\right) / \ln \left(\mathrm{K}_{1} / \mathrm{K}_{3}\right)-1\right)$

Figure 7. Stratigraphic correlation of the Cryogenian and Ediacaran successions of the 
Quruqtagh, Aksu and Yecheng areas in the Tarim block according to the zircon $\mathrm{U}-\mathrm{Pb}$ dating of volcanic layers and chemostratigraphic comparisons $(\mathrm{Xu}$ et al., 2009; 2013; Xiao et al., 2004; He et al., 2007; Tong et al., 2013; Zhu and Wang, 2011). The age assignment is based on the geological time scale of Gradstein et al., (2004). The stars show paleomagnetical sampling position in the Neoproterozoic strata by this and previous studies.

Figure 8. (a), Apparent Polar Wander Path (APWP) of the Tarim block from the Neoproterozoic to Present. The poles used to build this APWP are listed in Table 2. (b), Comparison of APWPs of Tarim and Australia (East Gondwana). Australian APWP (cross and dotted circle) is plotted in Australian coordinates with Neoproterozoic poles from Sohl et al. (1999), Wingate and Giddings (2000), Schimidt et al. (2009) and Li and Evans, (2011) and Paleozoic poles from McElhinny et al. (2003). The APWP of Tarim was rotated to the Australian coordinates around an Euler pole at $45.9^{\circ} \mathrm{S}, 277.6^{\circ} \mathrm{E}$ with an angle of $-43.4^{\circ}$.

Figure 9. Paleogeographic reconstruction of the major part of Rodinia at ca. $635 \mathrm{Ma}$ in Australian coordinate, showing the relative position of Australia, East Antarctica, Tarim, South China and India (modified from Li and Evans, 2011; Zhang et al., 2013). This reconstruction is made by rotating the Neoproterozoic to Early Paleozoic poles (crosses with 95\% confidence levels) of Tarim, which coincide with those of Australia, $43.4^{\circ} \mathrm{CCW}$ around an Euler pole at $277.6^{\circ} \mathrm{E}$ 
and $45.9^{\circ} \mathrm{S}$. Australia is at its present location. Positions 1 and 2 of South China and India represent the possible locations of these two blocks in Australian coordinate during the breakup of Rodiania. 
Table 1. Summarized paleomagnetic sampling and measurement results of this study.

\begin{tabular}{|c|c|c|c|c|c|c|c|c|c|c|c|c|c|c|}
\hline Site & Lithology & $\begin{array}{c}\text { Slong } \\
\text { (E) }\end{array}$ & $\begin{array}{l}\text { Slat } \\
(\mathrm{N})\end{array}$ & $\mathrm{n} / \mathrm{N}$ & Polarity & $\begin{array}{l}\mathrm{Dg} \\
\left({ }^{\circ}\right)\end{array}$ & $\begin{array}{l}\text { Ig } \\
\left({ }^{\circ}\right)\end{array}$ & $\begin{array}{l}\text { Ds } \\
\left({ }^{\circ}\right)\end{array}$ & $\begin{array}{l}\text { Is } \\
\left({ }^{\circ}\right)\end{array}$ & $\begin{array}{l}\mathrm{K} \\
\left({ }^{\circ}\right)\end{array}$ & $\begin{array}{l}\mathrm{a}_{95} \\
\left({ }^{\circ}\right)\end{array}$ & $\begin{array}{c}\text { Strike } \\
\left(^{\circ}\right)\end{array}$ & $\begin{array}{l}\text { Dip } \\
\left({ }^{\circ}\right)\end{array}$ & Comment \\
\hline
\end{tabular}

Zhaobishan Formation- Quruqtagh area

Xishankou area



Heishan-Zhaobishan area

$601 \quad$ Sandstone

602 Sandstone

603 Sandstone

604 Sandstone

605 Sandstone

606 Sandstone

607 Sandstone

608 Sandstone

$87^{\circ} 46^{\prime 2} 24^{\prime \prime} \quad 41^{\circ} 24^{\prime} 29^{\prime \prime}$

87०46'24" 41024'29"

87046'24" 41 $24^{\circ} 29^{\prime \prime}$

87066'24" 41'24'29"

$87^{\circ} 46^{\prime} 24^{\prime \prime} \quad 41^{\circ} 24^{\prime 2} 29^{\prime \prime}$

87046'24" 4124'29"

87046'24" 41024'29"

$87^{\circ} 46^{\prime 2} 24^{\prime \prime} \quad 41^{\circ} 24^{\prime 2} 2$ " $^{\prime \prime}$

Average

$4 / 7$
$3 / 7$
$6 / 7$
$6 / 7$
$7 / 7$
$7 / 7$
$5 / 7$
$5 / 7$
$8 / 8$

$\mathrm{N}$
$\mathrm{N}$
$\mathrm{N}$
$\mathrm{N}$
$\mathrm{N}$
$\mathrm{N}$
$\mathrm{N}$
$\mathrm{N}$

$\begin{array}{cccc}6.5 & 59.3 & 97.3 & 20.3 \\ 1.9 & 60.5 & 95.8 & 46.9 \\ 358.7 & 60.5 & 68.8 & 52.6 \\ 5.1 & 49.5 & 89.2 & 26.6 \\ 7.3 & 61.1 & 103.7 & 24.2 \\ 359.4 & 54.4 & 98.9 & 3 \\ 348.7 & 52.5 & 117.6 & 35.7 \\ 359.1 & 53.5 & 114.2 & 31.7 \\ \mathbf{0 . 6} & \mathbf{5 6 . 5} & & \end{array}$

$\begin{array}{lccccl}20.3 & 46.0 & 13.7 & 35.7 & 83.3 & \text { PEF } \\ 46.9 & 37.2 & 20.5 & 40.2 & 57.0 & \text { PEF } \\ 52.6 & 56.5 & 9.0 & 25.2 & 42.0 & \text { PEF } \\ 26.6 & 51.5 & 9.4 & 37.2 & 82.0 & \text { PEF } \\ 24.2 & 21.5 & 13.3 & 40.2 & 80.0 & \text { PEF } \\ 31.9 & 41.4 & 9.5 & 40.2 & 79.0 & \text { PEF } \\ 35.7 & 79.5 & 8.6 & 49.2 & 86.0 & \text { PEF } \\ 31.7 & 29.5 & 14.3 & 50.2 & 85.5 & \text { PEF } \\ & \mathbf{2 1 0 . 5} & \mathbf{3 . 8} & & & \\ \mathbf{3 4 . 4} & \mathbf{2 5 . 6} & \mathbf{1 1 . 2} & & & \end{array}$

Altungol Formation- Quruqtagh area

$\begin{array}{lllllllllllcccccc}609 & \text { Trachybasalt } & 87^{\circ} 46^{\prime} 24^{\prime \prime} & 41^{\circ} 24^{\prime} 29 " & 0 / 6 & - & - & - & - & - & - & - & - & - & \text { Dispersed } \\ 610 & \text { Trachybasalt } & 87^{\circ} 46^{\prime} 24^{\prime \prime} & 41^{\circ} 24^{\prime} 29^{\prime \prime} & 4 / 6 & \mathrm{~N} & 13.7 & 62.4 & 111.1 & 45.6 & 82.9 & 10.2 & 52.5 & 58.0 & \text { PEF } & \\ 611 & \text { Trachybasalt } & 87^{\circ} 46^{\prime} 24^{\prime \prime} & 41^{\circ} 24^{\prime} 29^{\prime \prime} & 4 / 6 & \mathrm{~N} & 12.7 & 64.6 & 114.1 & 45.3 & 139.4 & 7.8 & 52.5 & 58.0 & \text { PEF }\end{array}$




\begin{tabular}{|c|c|c|c|c|c|c|c|c|c|c|c|c|c|c|}
\hline 612 & Trachybasalt & $87^{\circ} 46^{\prime} 24^{\prime \prime}$ & $41^{\circ} 24^{\prime} 29^{\prime \prime}$ & $0 / 6$ & - & - & - & - & - & - & - & - & - & Dispersed \\
\hline 613 & Trachybasalt & $87^{\circ} 46^{\prime} 24^{\prime \prime}$ & $41^{\circ} 24^{\prime} 29^{\prime \prime}$ & $3 / 6$ & $\mathrm{~N}$ & 19.1 & 56.4 & 101.9 & 44.2 & 34.6 & 21.3 & 52.5 & 58.0 & PEF \\
\hline 614 & Trachybasalt & $87^{\circ} 46^{\prime} 24^{\prime \prime}$ & $41^{\circ} 24^{\prime} 29^{\prime \prime}$ & $6 / 6$ & $\mathrm{~N}$ & 3.2 & 60.3 & 111.0 & 51.0 & 298.4 & 3.9 & 52.5 & 58.0 & PEF \\
\hline 615 & Trachybasalt & $87^{\circ} 46^{\prime} 28^{\prime \prime}$ & $41^{\circ} 24^{\prime} 18^{\prime \prime}$ & $5 / 6$ & $\mathrm{~N}$ & 346.3 & 59.0 & 118.4 & 58.6 & 157.0 & 6.3 & 52.5 & 58.0 & PEF \\
\hline \multirow[t]{3}{*}{616} & Trachybasalt & $87^{\circ} 46^{\prime} 28^{\prime \prime}$ & $41^{\circ} 24^{\prime} 18^{\prime \prime}$ & $6 / 6$ & $\mathrm{~N}$ & 355.8 & 45.5 & 89.6 & 60.8 & 82.1 & 7.4 & 52.5 & 58.0 & PEF \\
\hline & Average & & & $6 / 8$ & & 4.4 & 58.6 & & & 74.3 & 7.8 & & & \\
\hline & & & & & & & & 108.1 & 51.2 & 74.6 & 7.8 & & & \\
\hline \multicolumn{15}{|c|}{ Tereeken Formation- Quruqtagh area } \\
\hline 617 & Carbonate & $87^{\circ} 48^{\prime} 50^{\prime \prime}$ & $41^{\circ} 27^{\prime} 08^{\prime \prime}$ & $4 / 7$ & $\mathrm{~N}$ & 97.1 & 45.5 & 101.2 & 62.3 & 27.1 & 19 & 179.2 & 17.0 & \\
\hline 618 & Carbonate & $87^{\circ} 48^{\prime} 50^{\prime \prime}$ & $41^{\circ} 27^{\prime} 08^{\prime \prime}$ & $4 / 7$ & $\mathrm{~N}$ & 114.1 & 36.4 & 94.0 & 63.1 & 25.4 & 25.0 & 224.2 & 29.0 & \\
\hline 619 & Carbonate & $87^{\circ} 48^{\prime} 50^{\prime \prime}$ & $41^{\circ} 27^{\prime} 08^{\prime \prime}$ & $7 / 7$ & $\mathrm{~N}$ & 79.2 & 61.3 & 115.7 & 64.4 & 55.2 & 8.3 & 106.7 & 18.5 & \\
\hline 620 & Carbonate & $87^{\circ} 48^{\prime} 50^{\prime \prime}$ & $41^{\circ} 27^{\prime} 08^{\prime \prime}$ & $7 / 8$ & $\mathrm{~N}$ & 82.2 & 61.6 & 76.7 & 61.8 & 54.8 & 8.3 & 255.7 & 3.0 & \\
\hline 621 & Carbonate & $87^{\circ} 48^{\prime} 50^{\prime \prime}$ & $41^{\circ} 27^{\prime} 08^{\prime \prime}$ & $4 / 6$ & $\mathrm{~N}$ & 112.2 & 54.3 & 92.8 & 59.1 & 62.2 & 11.7 & 261.7 & 13.5 & \\
\hline 622 & Carbonate & $87^{\circ} 48^{\prime} 42^{\prime \prime}$ & $41^{\circ} 27^{\prime} 03^{\prime \prime}$ & $4 / 6$ & $\mathrm{~N}$ & 96.4 & 52.9 & 62.4 & 65.7 & 160.5 & 8.4 & 227.7 & 23.0 & \\
\hline \multirow[t]{3}{*}{623} & Carbonate & $87^{\circ} 48^{\prime} 42^{\prime \prime}$ & $41^{\circ} 27^{\prime} 03^{\prime \prime}$ & $0 / 6$ & $\mathrm{~N}$ & - & - & - & - & - & - & 228.7 & 35.0 & dispersed \\
\hline & Average & & & $6 / 7$ & & 98.8 & 52.7 & & & 39.4 & 10.8 & \multirow{2}{*}{\multicolumn{3}{|c|}{$\begin{array}{c}\lambda=27.6^{\circ}, \quad=140.4^{\circ}, \mathrm{dp}=8.8^{\circ}, \\
\mathrm{dm}=11.1^{\circ}\end{array}$}} \\
\hline & & & & & & & & 90.8 & 63.7 & 91.4 & 7.0 & & & \\
\hline \multicolumn{15}{|c|}{ Zhamoketi Formation- Quruqtagh area } \\
\hline S05 & Basaltic andesite & $87^{\circ} 52^{\prime} 57^{\prime \prime}$ & $41^{\circ} 27^{\prime} 41^{\prime \prime}$ & $4 / 8$ & $\mathrm{~N}$ & 45.3 & 65.9 & 112 & 40.1 & 83.6 & 10.1 & 53.8 & 49.0 & \\
\hline S06 & Basaltic andesite & $87^{\circ} 52^{\prime} 57^{\prime \prime}$ & $41^{\circ} 27^{\prime} 41^{\prime \prime}$ & $8 / 8$ & $\mathrm{~N}$ & 73.6 & 63.2 & 115.1 & 28.1 & 108.7 & 5.3 & 53.8 & 49.0 & \\
\hline S07 & Basaltic andesite & $87^{\circ} 52^{\prime} 57^{\prime \prime}$ & $41^{\circ} 27^{\prime} 41^{\prime \prime}$ & $4 / 8$ & $\mathrm{~N}$ & 63.4 & 65.8 & 114.9 & 33.2 & 115.4 & 8.6 & 53.8 & 49.0 & \\
\hline S08 & Basaltic andesite & $87^{\circ} 52^{\prime} 57^{\prime \prime}$ & $41^{\circ} 27^{\prime} 41^{\prime \prime}$ & $3 / 8$ & $\mathrm{~N}$ & 50.1 & 65.1 & 111.6 & 38 & 220.7 & 8.3 & 53.8 & 49.0 & \\
\hline S09 & Basaltic andesite & $87^{\circ} 52^{\prime} 57^{\prime \prime}$ & $41^{\circ} 27^{\prime} 41^{\prime \prime}$ & $0 / 7$ & - & - & - & - & - & - & - & 53.8 & 49.0 & Dispersed \\
\hline $\mathrm{S} 10$ & Basaltic andesite & $87^{\circ} 52^{\prime} 57^{\prime \prime}$ & $41^{\circ} 27^{\prime} 41^{\prime \prime}$ & $5 / 8$ & $\mathrm{~N}$ & 52.1 & 69.8 & 117.7 & 38.6 & 524.6 & 3.3 & 53.8 & 49.0 & \\
\hline S11 & Basaltic andesite & $87^{\circ} 52^{\prime} 57^{\prime \prime}$ & $41^{\circ} 27^{\prime} 41^{\prime \prime}$ & $7 / 8$ & $\mathrm{~N}$ & 72.4 & 69.2 & 120.5 & 31.9 & 115.5 & 5.6 & 53.8 & 49.0 & \\
\hline
\end{tabular}




\begin{tabular}{|c|c|c|c|c|c|c|c|c|c|c|c|c|c|c|}
\hline $\mathrm{S} 12$ & Basaltic andesite & $87^{\circ} 52^{\prime} 57^{\prime \prime}$ & $41^{\circ} 27^{\prime} 41^{\prime \prime}$ & $0 / 8$ & - & - & - & - & - & - & - & 53.8 & 49.0 & Dispersed \\
\hline S13 & Basaltic andesite & $87^{\circ} 52^{\prime} 57^{\prime \prime}$ & $41^{\circ} 27^{\prime} 41^{\prime \prime}$ & $0 / 8$ & - & - & - & - & - & - & - & 53.8 & 49.0 & Dispersed \\
\hline 628 & Basaltic andesite & $87^{\circ} 52^{\prime} 14^{\prime \prime}$ & $41^{\circ} 26^{\prime} 19^{\prime \prime}$ & $0 / 6$ & - & - & - & - & - & - & - & 93.5 & 43.5 & Viscous \\
\hline 629 & Basaltic andesite & $87^{\circ} 52^{\prime} 14^{\prime \prime}$ & $41^{\circ} 26^{\prime} 19^{\prime \prime}$ & $0 / 6$ & - & - & - & - & - & - & - & 86.0 & 44.0 & Viscous \\
\hline 630 & Basaltic andesite & $87^{\circ} 52^{\prime} 05^{\prime \prime}$ & $41^{\circ} 26^{\prime} 24^{\prime \prime}$ & $0 / 6$ & - & - & - & - & - & - & - & 88.5 & 42.5 & Viscous \\
\hline 631 & Basaltic andesite & $87^{\circ} 52^{\prime} 05^{\prime \prime}$ & $41^{\circ} 26^{\prime} 24^{\prime \prime}$ & $0 / 6$ & - & - & - & - & - & - & - & 67.0 & 62.0 & Viscous \\
\hline & Average & & & $6 / 13$ & & 59.6 & 66.9 & & & 222.6 & 4.5 & \multirow{2}{*}{\multicolumn{3}{|c|}{ 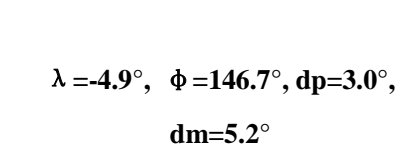 }} \\
\hline & & & & & & & & 115.4 & 35.0 & 223.9 & 4.5 & & & \\
\hline \multicolumn{15}{|c|}{ Shuiquan Formation- Quruqtagh area } \\
\hline S01 & Basalt & $87^{\circ} 52^{\prime} 52^{\prime \prime}$ & $41^{\circ} 25^{\prime} 51^{\prime \prime}$ & $0 / 7$ & - & - & - & - & - & - & - & 244.3 & 23.1 & \multirow[t]{6}{*}{ dispersed } \\
\hline $\mathrm{S} 02$ & Basalt & $87^{\circ} 52^{\prime} 52^{\prime \prime}$ & $41^{\circ} 25^{\prime} 51^{\prime \prime}$ & $6 / 7$ & $\mathrm{~N}$ & 359.1 & 30.1 & 356.7 & 15.6 & 13.1 & 19.2 & 244.3 & 23.1 & \\
\hline $\mathrm{S} 03$ & Basalt & $87^{\circ} 52^{\prime} 29^{\prime \prime}$ & $41^{\circ} 26^{\prime} 48^{\prime \prime}$ & $6 / 7$ & $\mathrm{~N}$ & 344.3 & 24.6 & 343.5 & -8.8 & 14.0 & 18.5 & 243.9 & 33.9 & \\
\hline \multirow[t]{3}{*}{ S04 } & Basalt & $87^{\circ} 52^{\prime} 29^{\prime \prime}$ & $41^{\circ} 26^{\prime} 48^{\prime \prime}$ & $4 / 7$ & $\mathrm{~N}$ & 352.9 & 13.3 & 353.3 & -5.0 & 10.7 & 19.4 & 243.9 & 33.9 & \\
\hline & Average & & & $3 / 4$ & & 352.0 & 22.8 & & & 55.4 & 16.7 & & & \\
\hline & & & & & & & & 351.1 & 0.6 & 30.2 & 22.8 & & & \\
\hline \multicolumn{15}{|c|}{ Hancalchough Formation- Quruqtagh area } \\
\hline 501 & Carbonate & $87^{\circ} 48^{\prime} 55^{\prime \prime}$ & $41^{\circ} 24 ' 59^{\prime \prime}$ & $5 / 7$ & $\mathrm{~N}$ & 22.3 & 57.6 & 108.1 & 70.0 & 280.1 & 4.6 & 78.5 & 38.0 & PEF \\
\hline 502 & Carbonate & $87^{\circ} 48^{\prime} 55^{\prime \prime}$ & $41^{\circ} 24^{\prime} 59^{\prime \prime}$ & $7 / 7$ & $\mathrm{~N}$ & 12.8 & 65.1 & 134.5 & 72.0 & 35.6 & 10.4 & 78.5 & 38.0 & PEF \\
\hline 503 & Carbonate & $87^{\circ} 48^{\prime} 55^{\prime \prime}$ & $41^{\circ} 24^{\prime} 59^{\prime \prime}$ & $7 / 7$ & $\mathrm{~N}$ & 17.1 & 57.0 & 106.6 & 72.8 & 56.3 & 8.1 & 78.5 & 38.0 & PEF \\
\hline 504 & Carbonate & $87^{\circ} 48^{\prime} 55^{\prime \prime}$ & $41^{\circ} 24^{\prime} 59^{\prime \prime}$ & $6 / 7$ & $\mathrm{~N}$ & 24.2 & 57.9 & 109.0 & 68.9 & 84.0 & 7.4 & 78.5 & 38.0 & PEF \\
\hline 624 & Carbonate & $87^{\circ} 55^{\prime} 51^{\prime \prime}$ & $41^{\circ} 26 ' 50^{\prime \prime}$ & $5 / 6$ & $\mathrm{~N}$ & 22.5 & 57.3 & 48.3 & 23.7 & 210.4 & 5.3 & 347.2 & 43.0 & PEF \\
\hline 625 & Carbonate & $87^{\circ} 55^{\prime} 51^{\prime \prime}$ & $41^{\circ} 26 ' 50^{\prime \prime}$ & $5 / 6$ & $\mathrm{~N}$ & 16.4 & 64.0 & 50.7 & 31.1 & 83.9 & 8.7 & 340.2 & 43.0 & PEF \\
\hline 626 & Carbonate & $87^{\circ} 55^{\prime} 51^{\prime \prime}$ & $41^{\circ} 26 ' 50^{\prime \prime}$ & $5 / 6$ & $\mathrm{~N}$ & 26.5 & 55.1 & 47.8 & 16.3 & 41.6 & 12.0 & 340.2 & 48.0 & PEF \\
\hline \multirow[t]{2}{*}{627} & Carbonate & $87^{\circ} 55^{\prime} 51^{\prime \prime}$ & $41^{\circ} 26 ' 50^{\prime \prime}$ & $6 / 6$ & $\mathrm{~N}$ & 12.4 & 59.6 & 46.9 & 28.7 & 82.3 & 7.4 & 349.2 & 47.0 & PEF \\
\hline & Average & & & $8 / 8$ & & 19.6 & 59.3 & & & 331.1 & 3.0 & & & \\
\hline
\end{tabular}


$\begin{array}{llll}64.2 & 51.8 & 6.6 & 23.2\end{array}$

\begin{tabular}{|c|c|c|c|c|c|c|c|c|c|c|c|c|c|c|}
\hline & & & & & & & & & & & & & & \\
\hline X01 & Sandstone & 7701'34" & $37^{\circ} 07^{\prime} 44^{\prime \prime}$ & $12 / 12$ & M & 31.8 & -3.0 & 15.9 & -30.2 & 9.3 & 15.0 & 356.5 & 55.0 & \\
\hline X02 & Sandstone & 7701'34" & $37^{\circ} 07^{\prime} 44^{\prime \prime}$ & $0 / 8$ & - & - & - & - & - & - & - & 349.0 & 57.0 & dispersed \\
\hline X03 & Sandstone & 7701'17" & $37^{\circ} 07^{\prime} 46^{\prime \prime}$ & $0 / 7$ & - & - & - & - & - & - & - & 0.7 & 54.3 & dispersed \\
\hline X04 & Sandstone & $77^{\circ} 01^{\prime 2} 3^{\prime \prime}$ & $37^{\circ} 07^{\prime} 49^{\prime \prime}$ & $8 / 9$ & $\mathrm{R}$ & 1.2 & 37.4 & 8.5 & -16.4 & 14.8 & 14.9 & 309.0 & 63.0 & \\
\hline $\mathrm{X} 05$ & Sandstone & $77^{\circ} 01^{\prime} 22^{\prime \prime}$ & $37^{\circ} 07^{\prime} 49^{\prime \prime}$ & $0 / 10$ & - & - & - & - & - & - & - & 301.7 & 58.7 & dispersed \\
\hline X06 & Sandstone & 7701'22" & $37^{\circ} 07^{\prime} 49^{\prime \prime}$ & $8 / 12$ & M & 6.6 & 42.1 & 14.7 & -13.4 & 23.0 & 11.8 & 308.3 & 61.3 & \\
\hline X07 & Sandstone & $77^{\circ} 01^{\prime 22 "}$ & $37^{\circ} 07^{\prime} 49^{\prime \prime}$ & $7 / 11$ & M & 345.7 & 25.2 & 347.2 & -20.1 & 18.5 & 14.4 & 304.0 & 61.3 & \\
\hline 901 & Sandstone & 77º1'34" & $37^{\circ} 07^{\prime} 44^{\prime \prime}$ & $6 / 12$ & $\mathrm{R}$ & 7.0 & 38.2 & 9.5 & -22.1 & 20.3 & 17.4 & 292.6 & 59.4 & \\
\hline 902 & Sandstone & $77^{\circ} 01^{\prime} 17^{\prime \prime}$ & $37^{\circ} 07^{\prime} 46^{\prime \prime}$ & $7 / 11$ & M & 357.3 & -29.8 & 1.5 & -19.0 & 29.8 & 11.2 & 88.3 & 43.4 & \\
\hline 903 & Sandstone & 77º1'24" & $37^{\circ} 07^{\prime} 52^{\prime \prime}$ & $9 / 12$ & $\mathrm{R}$ & 357.7 & 44.1 & 8.2 & -11.9 & 27.9 & 11.6 & 298.0 & 60.0 & \\
\hline 904 & Sandstone & $77^{\circ} 01 ' 23^{\prime \prime}$ & $37^{\circ} 07^{\prime} 49^{\prime \prime}$ & $6 / 11$ & $\mathrm{R}$ & 13.5 & 55.0 & 21.4 & -11.9 & 19.2 & 17.9 & 304.0 & 66.5 & \\
\hline 905 & Sandstone & $77^{\circ} 01^{\prime} 21^{\prime \prime}$ & $37^{\circ} 08^{\prime} 01^{\prime \prime}$ & $0 / 12$ & - & - & - & - & - & - & - & 310.5 & 66.5 & dispersed \\
\hline & Average & & & $8 / 12$ & & 5.2 & 27.9 & & & 7.2 & 22.2 & & & \\
\hline
\end{tabular}

$\begin{array}{lllll}8.4 & -18.4 & 48.5 & 8.0 & \mathrm{dm}=8.3^{\circ}\end{array}$

Abbreviations: Lith, lithology; Slong/Slat, longitude and latitude of sampling site; $\mathrm{n} / \mathrm{N}$, number of samples used to calculate mean direction/number of demagnetized samples; N, R and M, magnetic normal, reversal and mixed polarities, respectively; Dg, Ig Ds, Is, declination and inclination in geographic and stratigraphic coordinates, respectively; $\mathrm{k}$, the best estimate of the precision parameter; $\alpha_{95}$, radius that mean direction lies within $95 \%$ confidence; $\lambda / \varphi$, latitude and longitude of paleomagnetic pole; dp/dm, oval of $95 \%$ confidence for the paleomagnetic pole. PEF, present earth field. 
Table 2. Paleomagnetic poles for the Tarim bock from the Neoproterozoic to the Present

\begin{tabular}{|c|c|c|c|c|c|c|c|c|c|}
\hline Age & $\mathbf{N}$ & $\begin{array}{c}\text { SLAT } \\
\left({ }^{\circ} \mathrm{N}\right)\end{array}$ & $\begin{array}{c}\text { SLON } \\
\left({ }^{\circ} \mathrm{E}\right)\end{array}$ & $\begin{array}{c}\text { PLAT } \\
\left({ }^{\circ} \mathrm{N}\right)\end{array}$ & $\begin{array}{c}\text { PLON } \\
\left({ }^{\circ} \mathrm{E}\right)\end{array}$ & $\begin{array}{c}\text { dp/A95 } \\
\left(^{\circ}\right)\end{array}$ & $\begin{array}{l}\mathbf{d m} \\
\left({ }^{\circ}\right)\end{array}$ & Reference & Comment \\
\hline \multicolumn{10}{|c|}{ Neoproterozoic } \\
\hline$* \mathrm{NP} 2,775$ & $9 \mathrm{~S}$ & 41.1 & 80.1 & 19.0 & 128.0 & 6.0 & 7.0 & Chen et al., 2004 & RT \\
\hline $\mathrm{NP} 2,740$ & $6 \mathrm{~S}$ & 41.6 & 86.5 & -17.7 & 14.2 & 3.0 & 6.0 & Huang et al., 2004 & Remag. \\
\hline $\mathrm{NP} 2,730$ & $14 \mathrm{~S}$ & 40.9 & 79.5 & -6.3 & 17.5 & 9.1 & & Wen et al., 2013 & \\
\hline *NP3, 635 & $6 \mathrm{~S}$ & 41.5 & 87.8 & 27.6 & 140.4 & 8.8 & 11.1 & This study & FT \\
\hline$* N P 3,625$ & $24 S$ & 41.0 & 80.0 & 19.1 & 149.7 & 9.3 & & Zhan et al., 2007 & $\mathrm{FT}, \mathrm{N}+\mathrm{R}$ \\
\hline NP3, 625 & $29 \mathrm{~S}$ & 41.0 & 80.0 & 55.0 & 233.0 & 7.9 & & Li et al., 1991 & Remag. \\
\hline *NP3, 615 & $6 \mathrm{~S}$ & 41.5 & 87.8 & -4.9 & 146.7 & 3.0 & 5.2 & This study & \\
\hline \multicolumn{10}{|c|}{ Early Ordovician } \\
\hline$* 480$ & $5 \mathrm{~S}$ & 41.3 & 83.4 & -20.4 & 180.6 & 8.5 & 15.0 & Fang et al., 1996 & \\
\hline \multicolumn{10}{|l|}{ Late Ordovician } \\
\hline$* 450$ & $5 \mathrm{~S}$ & 40.6 & 78.9 & -40.7 & 183.3 & 4.8 & 6.9 & Sun and Huang, 2009 & FT \\
\hline \multicolumn{10}{|l|}{ Middle Silurian } \\
\hline $\mathrm{S}_{2}$ & $6 \mathrm{~S}$ & 40.5 & 79.7 & 12.1 & 158.4 & 4.1 & 7.2 & Fang et al., 1996 & \\
\hline $\mathrm{S}_{2}$ & $40 \mathrm{~S}$ & 40.6 & 79.0 & 16.5 & 165.2 & 2.9 & 5.3 & Li et al., 1990 & \\
\hline $\mathrm{S}_{2}$ & $18 \mathrm{~S}$ & 40.6 & 79.4 & 9.9 & 160.2 & 4.5 & 8.4 & Fang et al., 1992 & \\
\hline$*$ Ave, 425 & $3 / 3$ & & & 12.8 & 159.8 & 7.3 & & & \\
\hline \multicolumn{10}{|c|}{ Early-middle Devonian } \\
\hline$* 400$ & $3 \mathrm{~S}$ & 40.5 & 79.6 & 13.5 & 160.8 & 4.9 & & Fang et al, 1996 & \\
\hline \multicolumn{10}{|l|}{ Late Devonian } \\
\hline$* 370$ & $47 \mathrm{~S}$ & 40.5 & 78.6 & 16.5 & 165.0 & 4.3 & & Li et al, 1990 & FT, RT \\
\hline \multicolumn{10}{|c|}{ Late Carboniferous } \\
\hline$* 310$ & $3 \mathrm{~L}$ & & & 48.7 & 175.7 & 3.0 & 4.8 & Fang et al., 1998 & \\
\hline \multicolumn{10}{|c|}{ Early Permian } \\
\hline $\mathrm{C}_{3}-\mathrm{P}_{2}$ & $15 \mathrm{~S}$ & 37.0 & 79.0 & 64.6 & 166.5 & 2.5 & & Gilder et al., 1996 & FT \\
\hline $\mathrm{P}_{1}$ & $5 \mathrm{~S}$ & 40.6 & 79.5 & 56.1 & 179.4 & 2.5 & & Fang et al., 1998 & FT \\
\hline $\mathrm{P}_{1}$ & $26 \mathrm{~S}$ & 40.8 & 79.8 & 56.5 & 190.1 & 4.6 & & Bai et al., 1987 & \\
\hline $\mathrm{P}_{1}$ & $21 \mathrm{~S}$ & 40.5 & 78.8 & 54.5 & 172.3 & 4.0 & & Sharps et al., 1989 & FT \\
\hline $\mathrm{P}_{1}$ & $11 \mathrm{~S}$ & 40.5 & 78.8 & 65.1 & 162.5 & 4.1 & & Sharps et al., 1989 & FT \\
\hline *Ave, 280 & $5 / 5$ & & & 59.7 & 175.1 & 7.1 & & & \\
\hline \multicolumn{10}{|l|}{ Late Permian } \\
\hline $\mathrm{P}_{2}$ & $7 \mathrm{~S}$ & 44.0 & 88.1 & 75.8 & 195.0 & 13.6 & 18.5 & Nie, 1991 & FT, RT \\
\hline $\mathrm{P}_{2}$ & $24 \mathrm{~S}$ & 40.8 & 79.8 & 62.9 & 190.7 & 6.3 & & Cheng et al., 1983 & \\
\hline $\mathrm{P}_{2}$ & $10 \mathrm{~S}$ & 42.1 & 83.4 & 73.2 & 191.0 & 7.2 & 10.3 & McFadden et al., 1988 & RT \\
\hline $\mathrm{P}_{3}$ & $21 \mathrm{~S}$ & 40.0 & 79.0 & 65.6 & 181.2 & 3.9 & & Li et al., 1988b, & RT \\
\hline $\mathrm{P}_{3}-\mathrm{T}_{1}$ & $16 \mathrm{~S}$ & 42.1 & 83.3 & 71.8 & 187.6 & 5.5 & 7.8 & McFadden et al., 1988 & FT \\
\hline
\end{tabular}


*Ave, $255 \quad 5 / 5$

$\begin{array}{lll}69.9 & 188.5 & 5.4\end{array}$

Triassic

\begin{tabular}{|c|c|c|c|c|c|c|c|c|c|}
\hline $\mathrm{T}_{1}$ & $5 \mathrm{~S}$ & 41.0 & 74.9 & 52.8 & 175.5 & 6.3 & 10.1 & Fang et al., 1992 & RT \\
\hline $\mathrm{T}_{2}$ & $26 \mathrm{~S}$ & 40.9 & 81.5 & 52.5 & 168.2 & 4.2 & 6.1 & Fang et al., 1992 & RT \\
\hline $\mathrm{T}_{3}$ & $8 \mathrm{~S}$ & 41.7 & 80.5 & 52.1 & 166.8 & 5.6 & 8.1 & Fang et al., 1992 & RT \\
\hline $\mathrm{T}$ & $6 \mathrm{~S}$ & 41.6 & 83.5 & 59.0 & 160.0 & 13.0 & & Li et al., 1990 & FT, RT \\
\hline $\mathrm{T}_{3}$ & $6 \mathrm{~S}$ & 42.1 & 83.2 & 69.3 & 182.9 & 10.8 & 15.2 & McFadden et al., 1988 & FT \\
\hline *Ave, 230 & $5 / 5$ & & & 57.3 & 169.9 & 8.1 & & & \\
\hline iddle Juras: & & & & & & & & & \\
\hline $\mathrm{J}_{2}$ & $10 \mathrm{~S}$ & 36.0 & 79.2 & 52.4 & 187.9 & 3.7 & 6.5 & Fang et al., 1992 & RT \\
\hline $\mathrm{J}_{2}$ & $7 \mathrm{~S}$ & 41.8 & 83.0 & 49.9 & 173.0 & 2.8 & 4.1 & Fang et al., 1992 & FT \\
\hline $\mathrm{J}_{2}$ & $9 \mathrm{~S}$ & 40.2 & 75.3 & 54.0 & 188.3 & 6.8 & & Meng et al., 1998 & FT,RT \\
\hline $\mathrm{J}_{2}$ & $6 \mathrm{~S}$ & 42.1 & 83.2 & 75.7 & 198.0 & 8.1 & & Gilder et al., 2008 & FT \\
\hline$* 170$ & $3 / 3$ & & & 52.3 & 182.8 & 8.8 & & & \\
\hline
\end{tabular}

Late Jurassic

$\begin{array}{cccccccccc}\mathrm{J}_{3} & 7 \mathrm{~S} & 40.4 & 75.2 & 81.0 & 247.0 & 5.0 & 7.6 & \text { Li et al., 2003 } & \text { FT } \\ \mathrm{J}_{3} & 6 \mathrm{~S} & 38.6 & 75.3 & 4.9 & 120.6 & 9.1 & 12.6 & \text { Li et al., 2003 } \\ \mathrm{J}_{3} & 3 \mathrm{~S} & 41.8 & 82.0 & 63.0 & 197.0 & 14.0 & & \text { Zhang et al., 1989 }\end{array}$

Early Cretaceous

$\begin{array}{cccccccccc}\mathrm{J}_{3}-\mathrm{K}_{1} & 13 \mathrm{~S} & 44.2 & 86.0 & 72.3 & 227.3 & 4.8 & 7.2 & \text { Chen et al., 1991 } & \text { FT, RT } \\ \mathrm{J}_{3}-\mathrm{K}_{1} & 6 \mathrm{~S} & 41.8 & 82.0 & 65.0 & 209.0 & 9.0 & & \text { Li et al., 1988b } & \text { RT } \\ \mathrm{K}_{1} & 13 \mathrm{~S} & 40.2 & 75.3 & 64.1 & 172.1 & 12.0 & & \text { Gilder et al., 2003 } & \text { FT } \\ \mathrm{K}_{1} & 5 \mathrm{~S} & 40.2 & 75.3 & 53.2 & 183.4 & 6.1 & & \text { Gilder et al., 2003 } & \text { FT } \\ \mathrm{K}_{1} & 7 \mathrm{~S} & 39.5 & 75.0 & 66.3 & 226.6 & 9.0 & 15.9 & \text { Chen et al., 1992 } & \text { RT } \\ \mathrm{K}_{1} & 3 \mathrm{~S} & 38.5 & 76.4 & 70.4 & 212.1 & 6.6 & 10.8 & \text { Chen et al., 1992 } & \text { RT } \\ \mathrm{K}_{1} & 8 \mathrm{~S} & 36.3 & 78.8 & 72.3 & 206.6 & 9.8 & 15.9 & \text { Zhu et al., 1998 } & \text { FT, RT } \\ \mathrm{K}_{1} & 21 \mathrm{~S} & 39.5 & 75.0 & 70.1 & 225.8 & 7.0 & & \text { Tan et al., 2003 } & \text { FT, RT } \\ \text { *Ave, 120 } & \mathbf{8 / 8} & & & \mathbf{6 8 . 0} & \mathbf{2 0 5 . 1} & \mathbf{7 . 2} & & & \end{array}$

Late Cretaceous

$\begin{array}{cccccccccc}\mathrm{K}_{2} & 7 \mathrm{~S} & 41.6 & 83.5 & 66.3 & 222.9 & 8.7 & 8.7 & \text { Li et al., 1988 } & \text { FT } \\ \mathrm{K}_{2} & 10 \mathrm{~S} & 42.0 & 82.9 & 64.0 & 229.0 & 7.3 & 12.7 & \text { Zhu et al., 1998 } & \text { RT } \\ \mathrm{K}_{2} & 11 \mathrm{~S} & 39.5 & 75.0 & 70.8 & 222.6 & 5.4 & 8.9 & \text { Chen et al., } 1992 & \text { FT } \\ \mathrm{K}_{2} & 6 \mathrm{~S} & 38.5 & 76.4 & 71.0 & 234.0 & 6.8 & 11.6 & \text { Chen et al., } 1992 & \text { RT } \\ \mathrm{K}_{2} \text {-E } & 9 \mathrm{~S} & 44.2 & 86.0 & 74.3 & 223.1 & 6.4 & 9.4 & \text { Chen et al., } 1991 & \text { FT, RT } \\ \text { *Ave, 80 } & \mathbf{5 / 5} & & & \mathbf{6 9 . 3} & \mathbf{2 2 6 . 4} & \mathbf{4 . 2} & & & \\ \text { Paleogene } & & & & & & & & & \\ \mathrm{E}_{1} & 4 \mathrm{~S} & 41.6 & 83.5 & 73.0 & 245.4 & 6.0 & 9.7 & \text { Fang et al., } 1998 & \\ \mathrm{E}_{1} & 5 \mathrm{~S} & 37.0 & 79.0 & 58.1 & 202.0 & 12.7 & & \text { Gilder et al., 1996 } & \text { FT } \\ \text { E-N } & 7 \mathrm{~S} & 38.1 & 86.6 & 75.8 & 229.5 & 9.6 & & \text { Y. Chen et al., 2002 } & \text { FT }\end{array}$




\begin{tabular}{|c|c|c|c|c|c|c|c|c|c|}
\hline $\mathrm{E}_{3}$ & $6 \mathrm{~S}$ & 39.2 & 94.3 & 63.9 & 219.7 & 9.8 & & Y. Chen et al., 2002 & FT \\
\hline $\mathrm{E}_{3}-\mathrm{N}_{1}$ & $9 \mathrm{~S}$ & 38.5 & 76.4 & 71.2 & 226.7 & 6.7 & & Chen et al., 1991 & FT \\
\hline *Ave, 50 & $5 / 5$ & & & 69.1 & 221.2 & 8.9 & & & \\
\hline \multicolumn{10}{|l|}{ Neogene } \\
\hline $16.5-5.7$ & $44 \mathrm{~S}$ & 42.0 & 83.3 & 75.5 & 285.1 & 2.2 & & Huang et al., 2006 & RT \\
\hline$* 10,(12.6-5.2)$ & $406 \mathrm{~s}$ & 41.9 & 83.3 & 72.5 & 284.5 & 1.4 & 2.2 & Charreau et al., 2006 & RT \\
\hline \multicolumn{10}{|l|}{ Quaternary } \\
\hline$* 2,(3.3-1.1)$ & $258 \mathrm{~s}$ & 39.8 & 76.2 & 73.9 & 297.5 & 1.9 & & J. Chen et al., 2002 & RT \\
\hline
\end{tabular}

Abbreviations: S, the number of the sites; N, number of localities (L), sites (S) or samples (s) used to determine pole; Slong/Slat, longitude and latitude of sampling site; Plat/Plong, latitude and longitude of paleomagnetic pole; $\mathrm{dp} / \mathrm{dm}$, oval of $95 \%$ confidence for the paleomagnetic pole; A95, radius that mean direction lies within $95 \%$ confidence; N+R, Normal and reversal polarities; FT, fold test; RT, reversal test.

Poles with * were used to build the Apparent Polar Wonder Path of Tarim. No mean pole was calculated for Late Jurassic because the three published Late Jurassic poles are not consistent. 


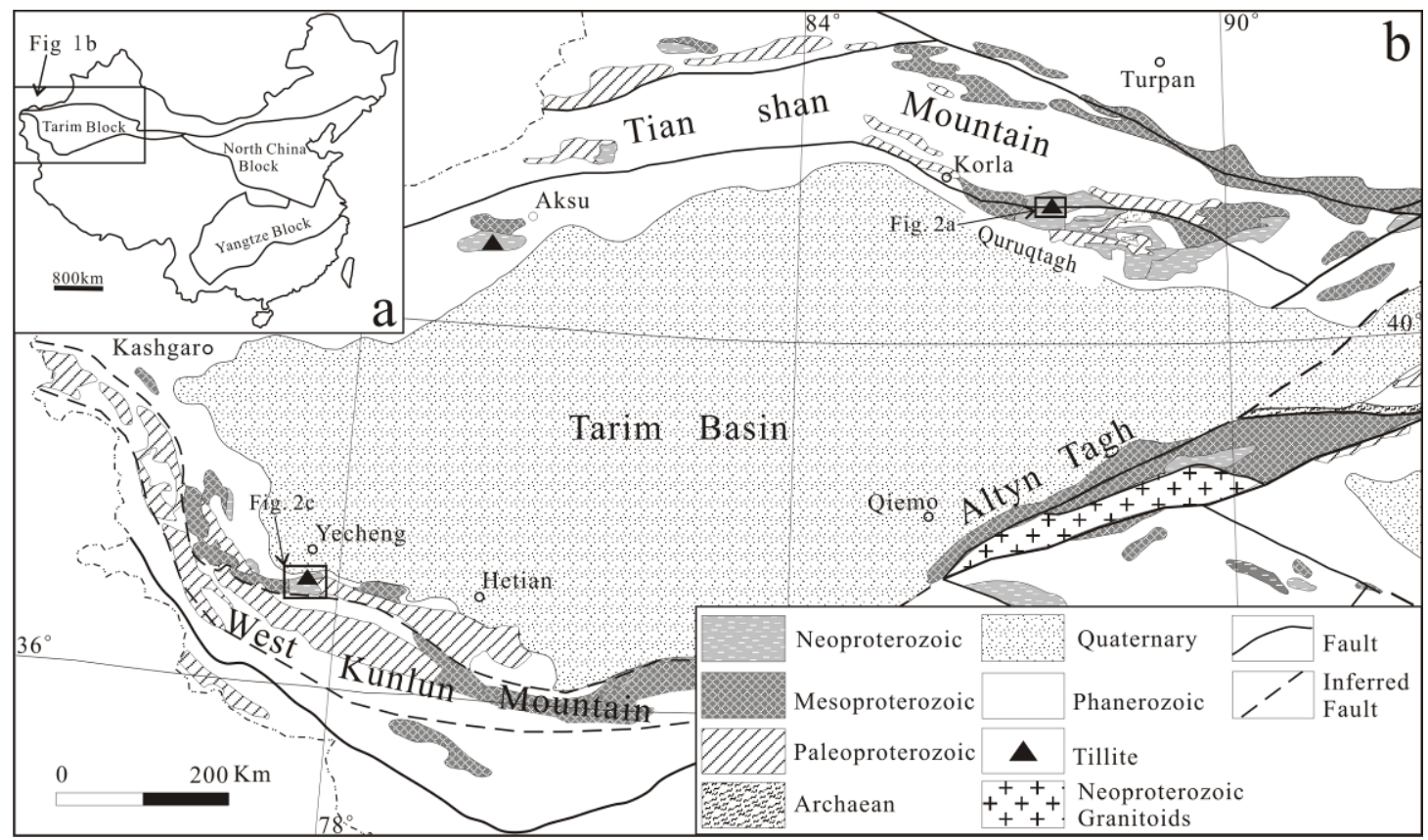

Figure 1 

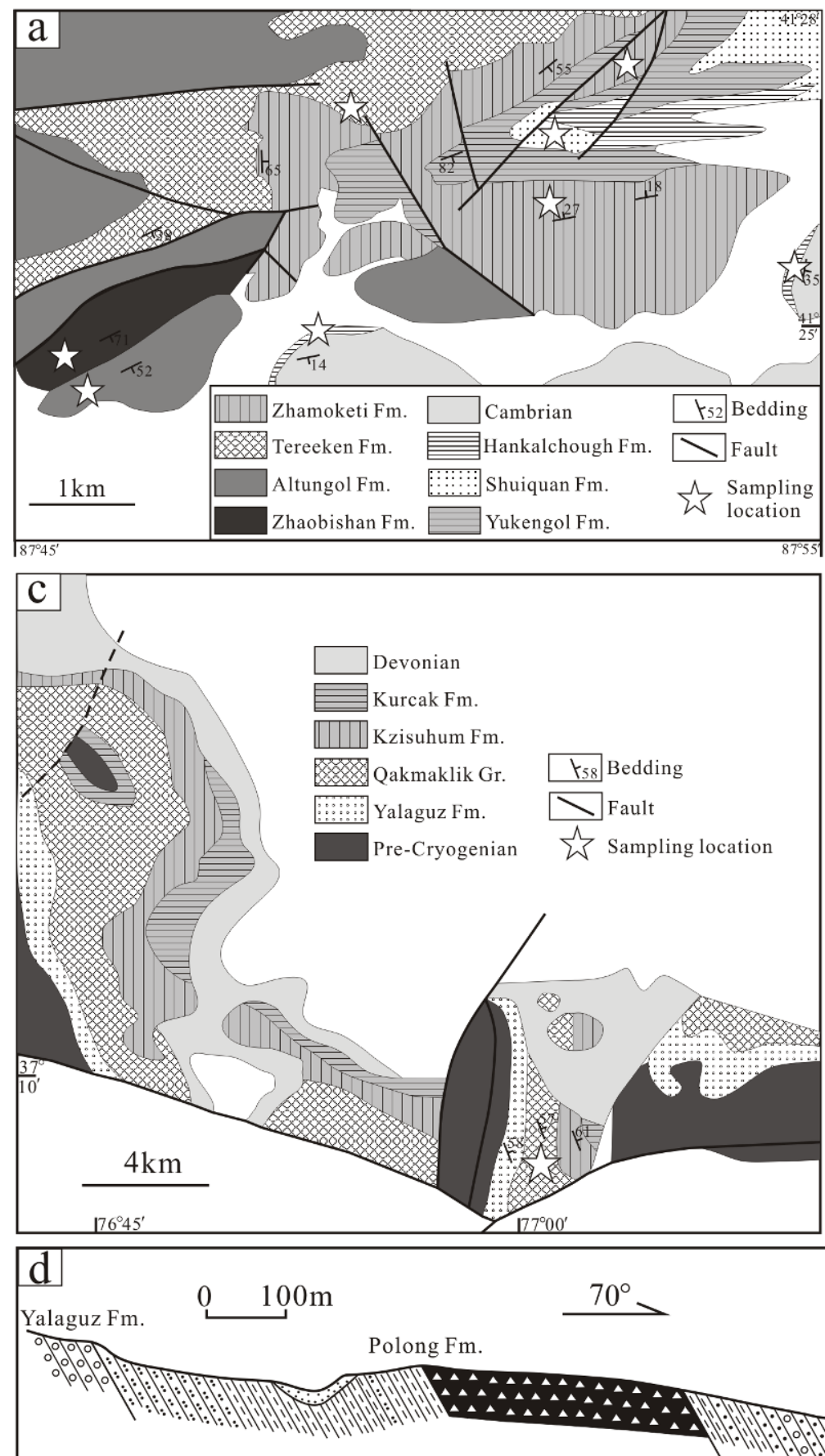

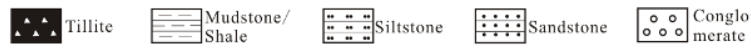

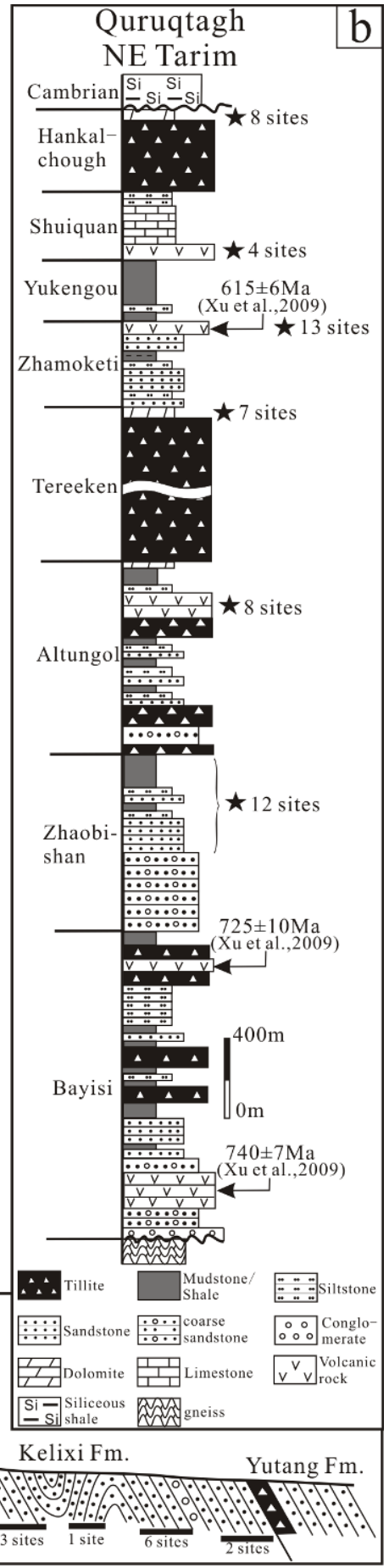

Figure 2 

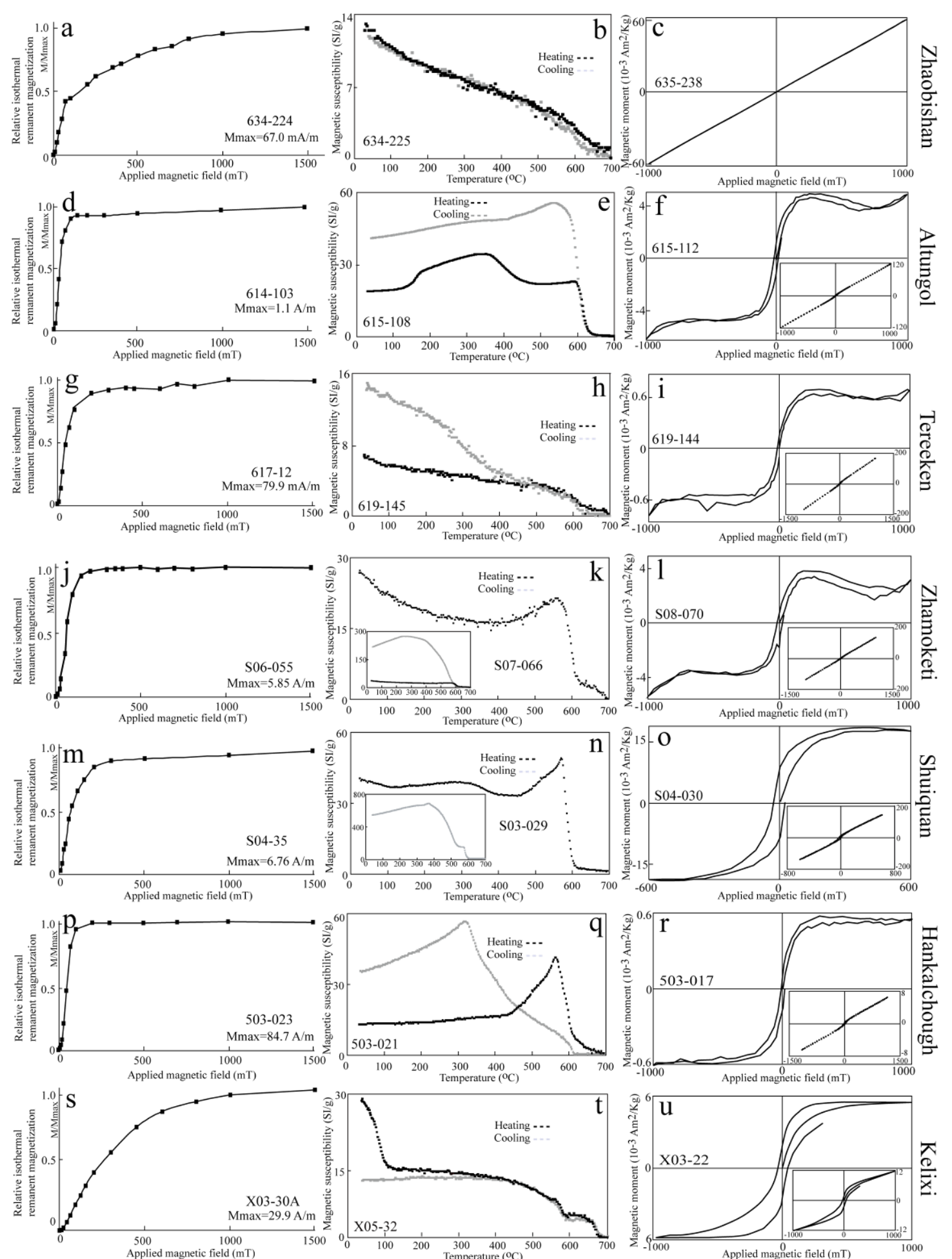

Figure 3 

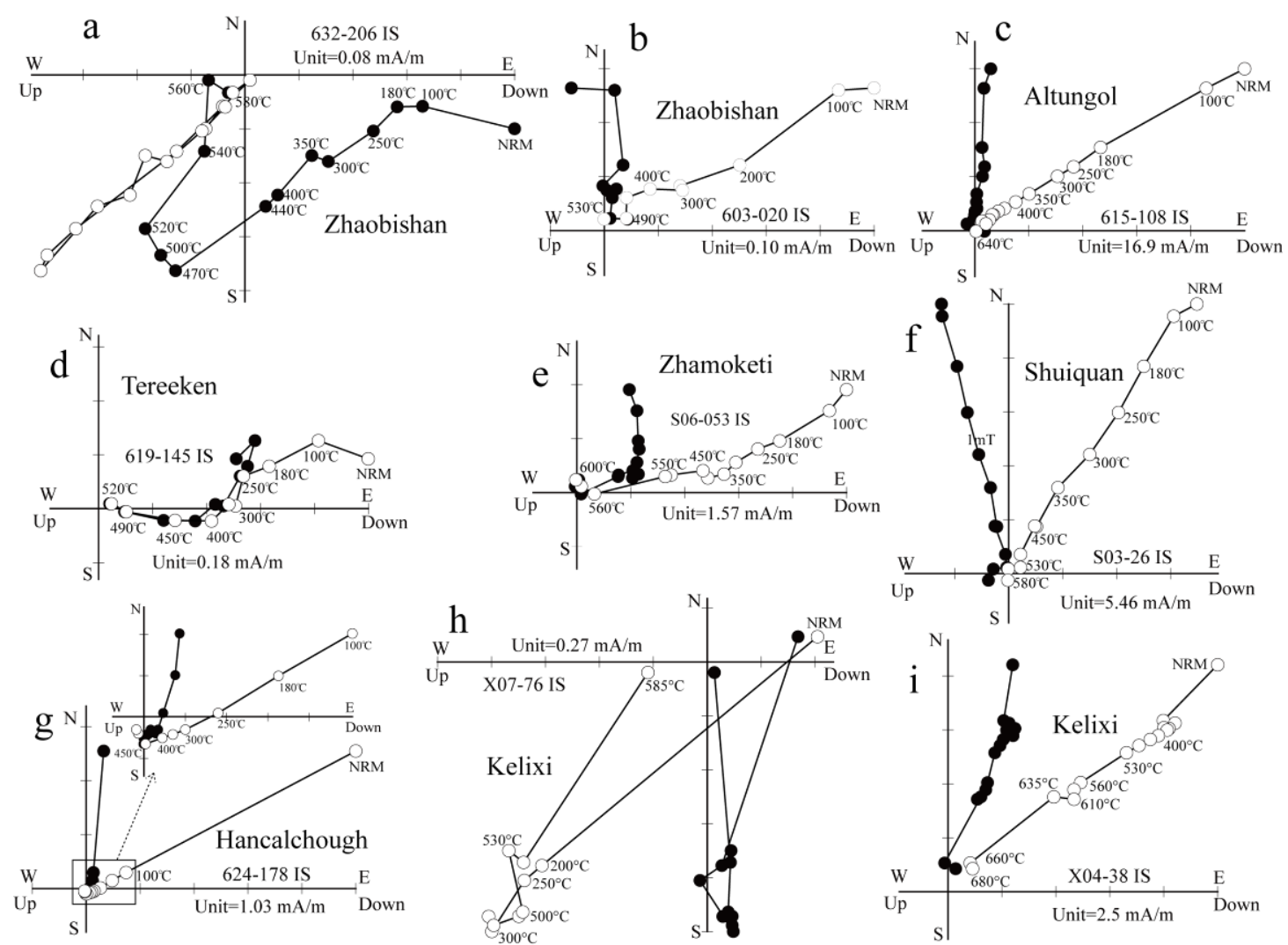

Figure 4 


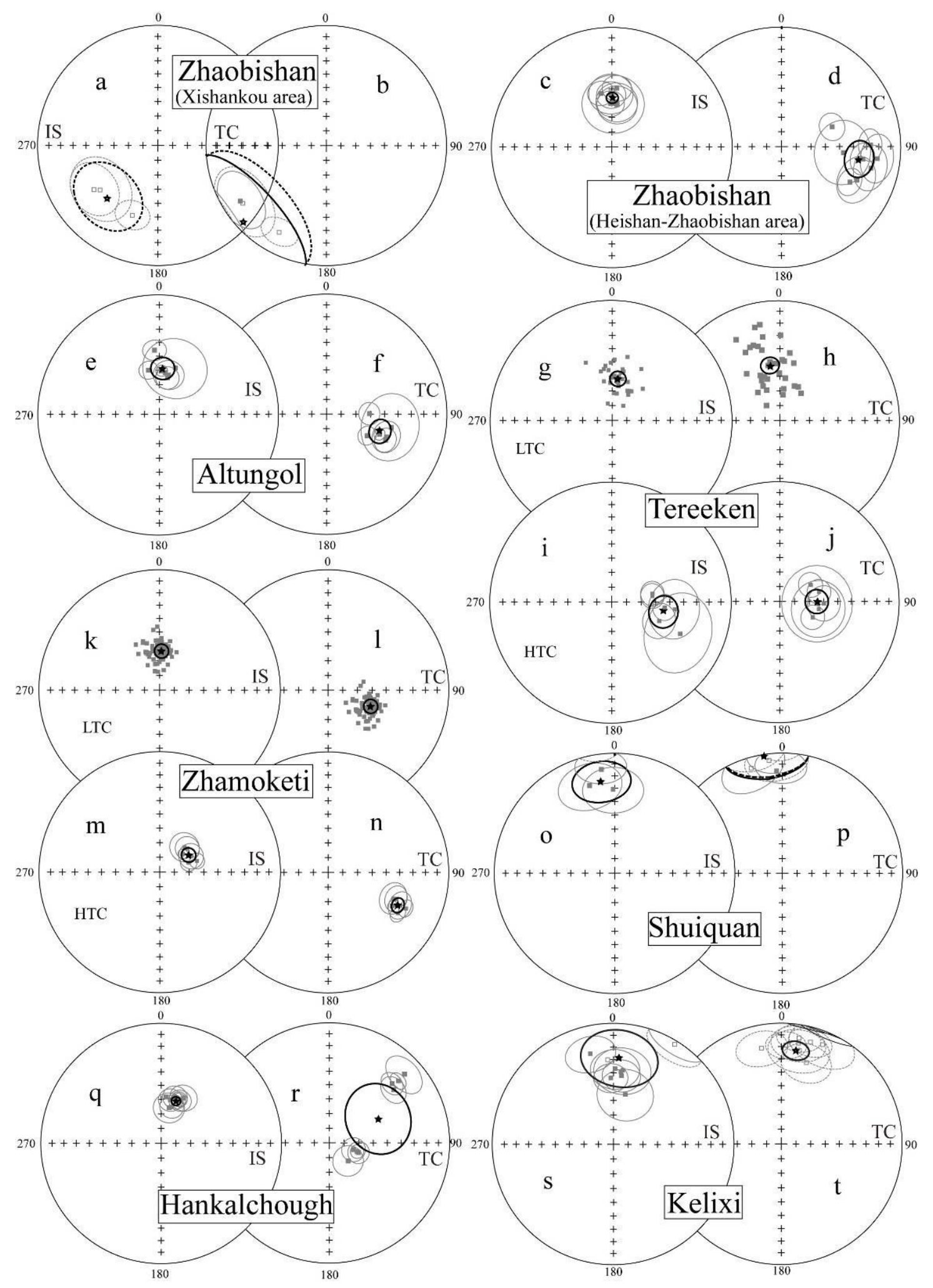

Figure 5 

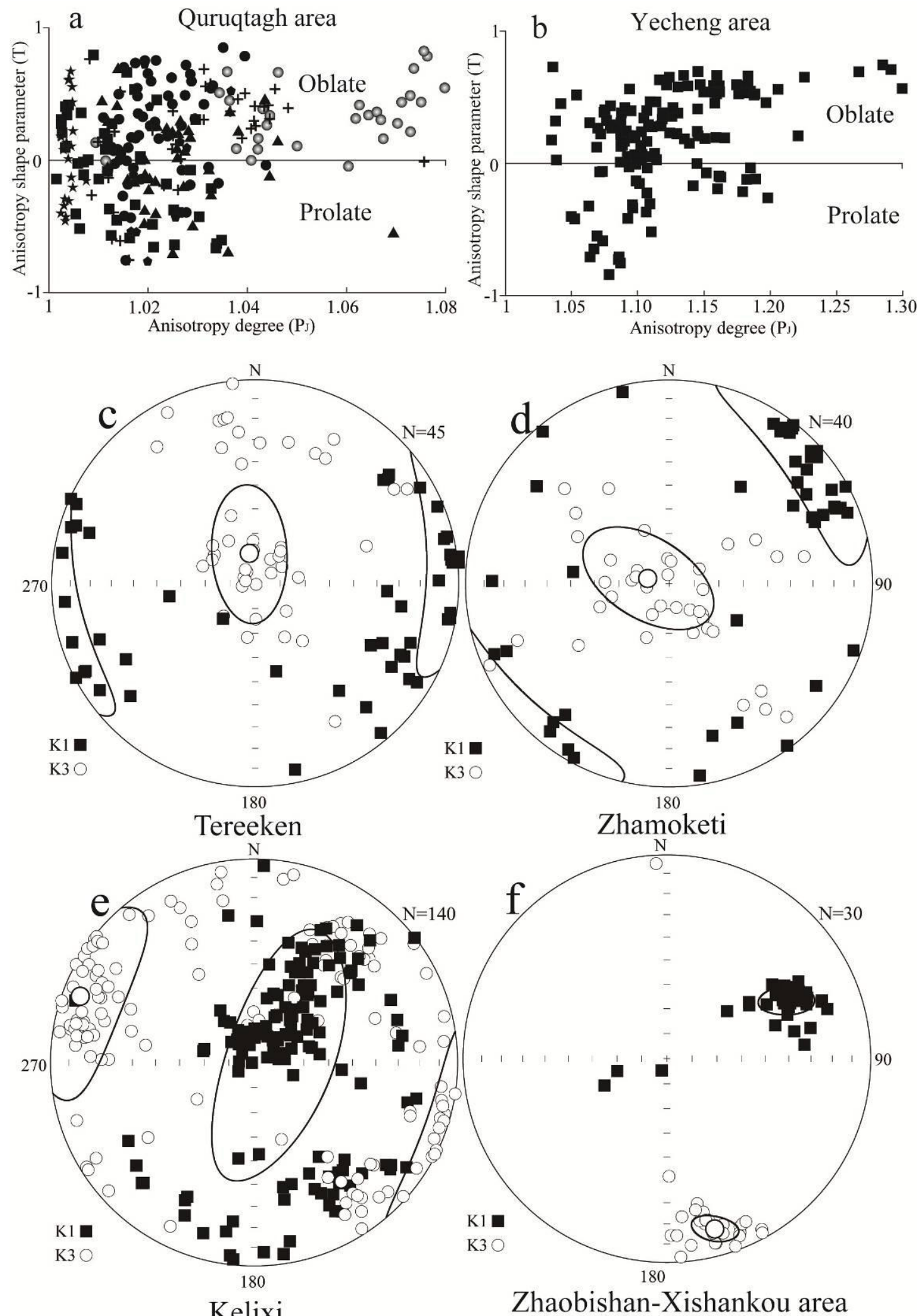

Figure 6 


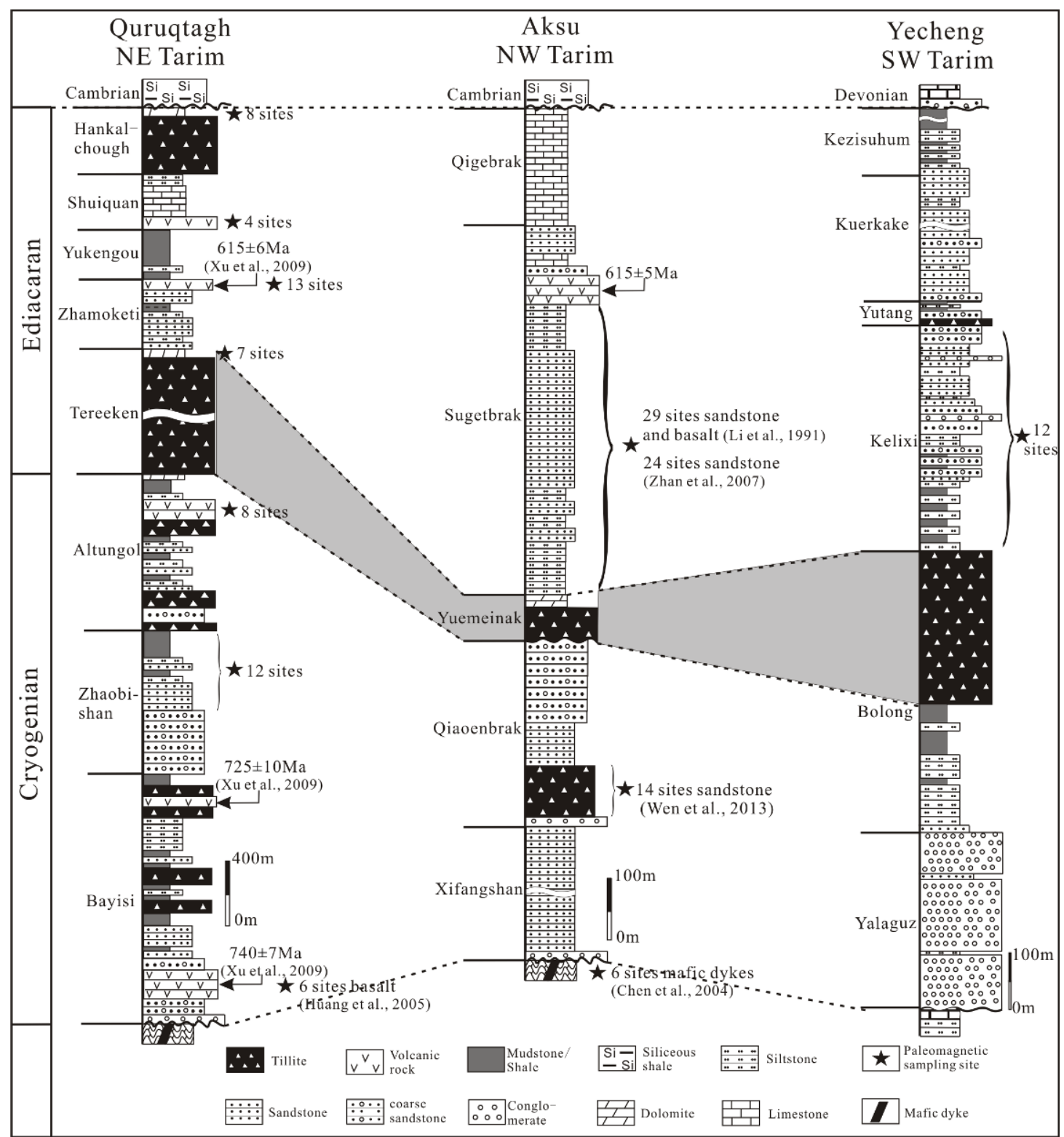

Figure 7 


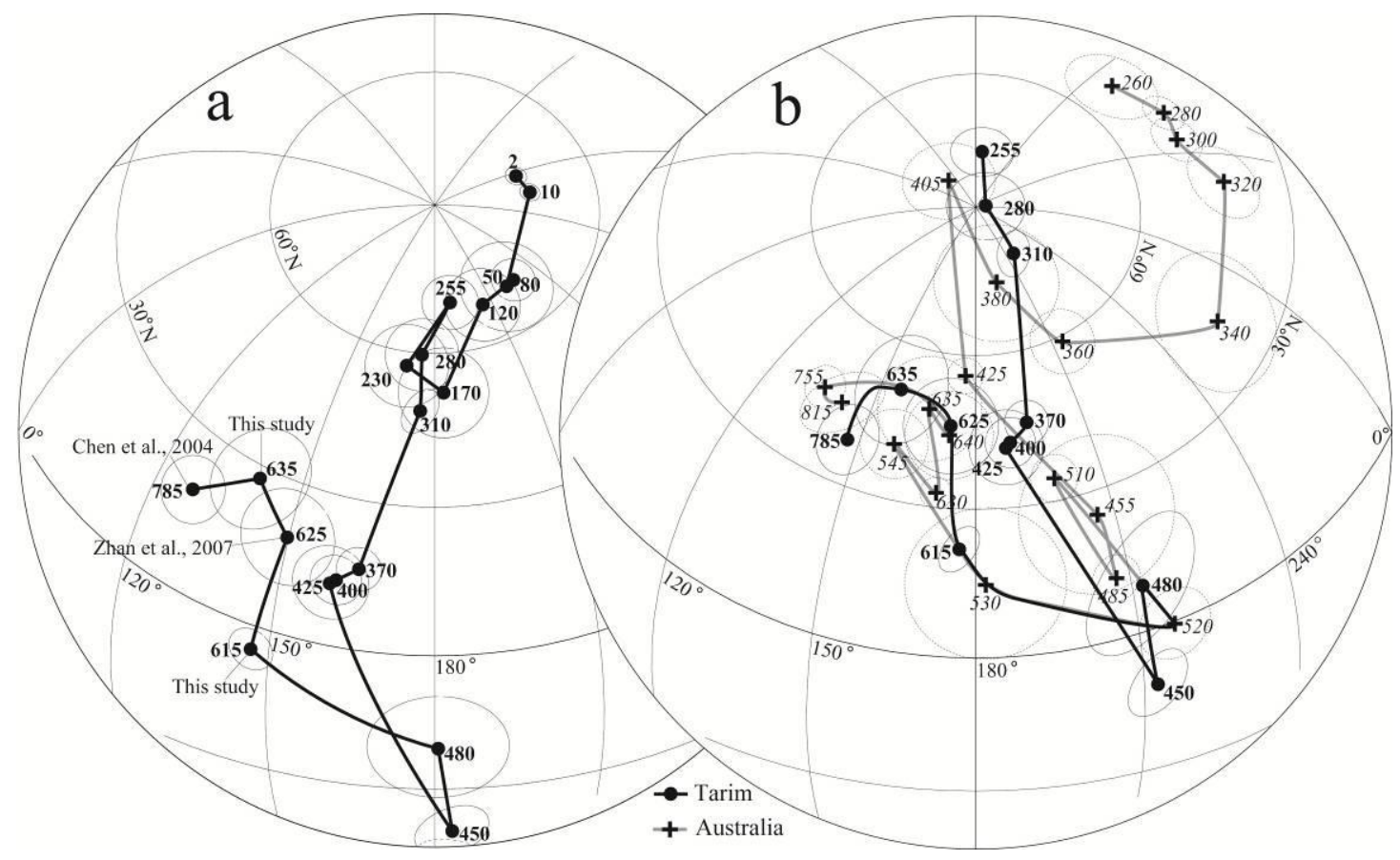

Figure 8 


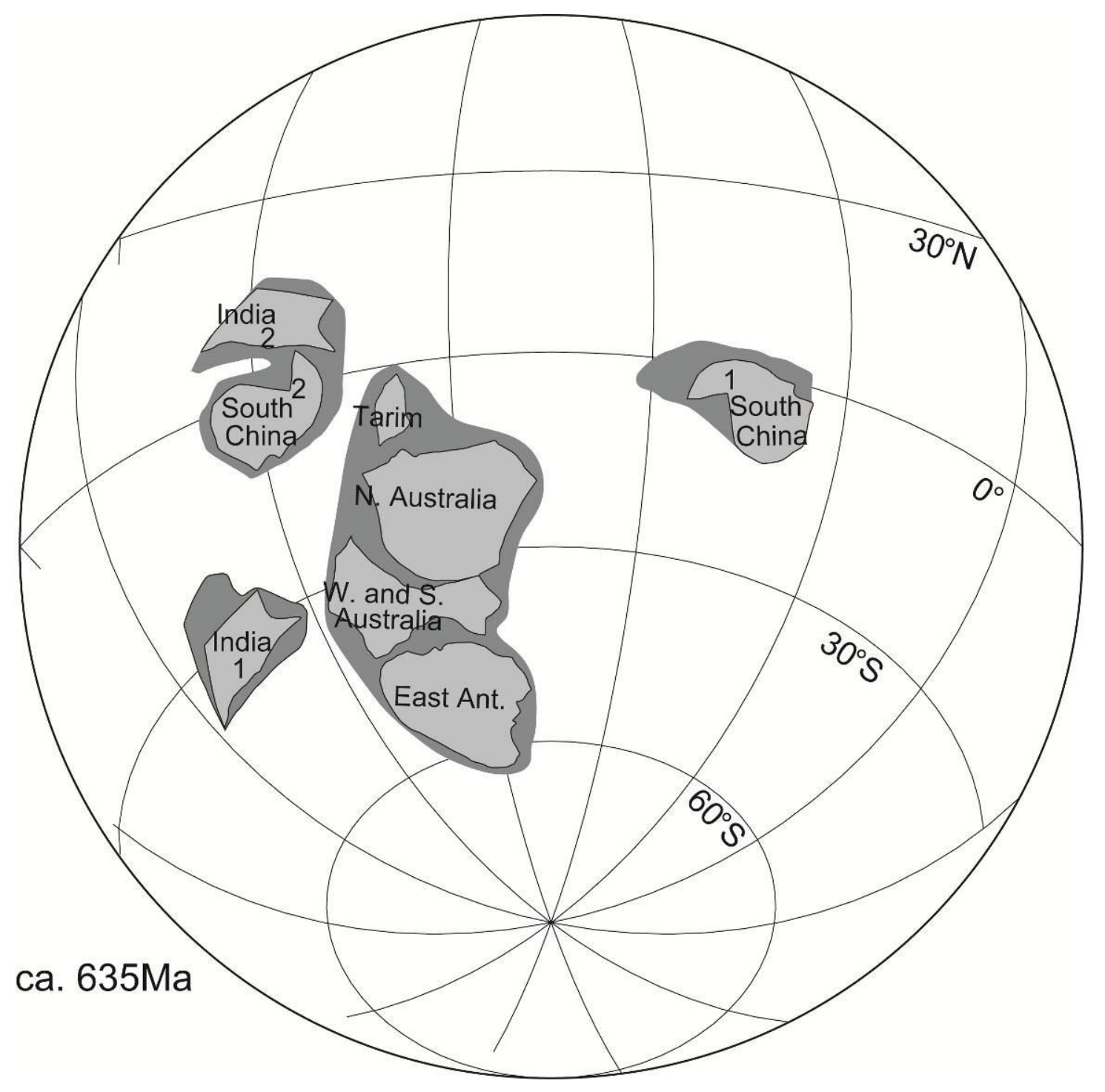

Figure 9 